\title{
GenePRIMP: A GENE PRediction IMprovement Pipeline for Prokaryotic genomes
}

Amrita Pati ${ }^{1}$, Natalia N. Ivanova ${ }^{1}$, Natalia Mikhailova ${ }^{1}$, Galina Ovchinnikova ${ }^{1}$, Sean D. Hooper $^{1,2}$, Athanasios Lykidis ${ }^{1}$ \& Nikos C. Kyrpides ${ }^{1}$

${ }^{1}$ Genome Biology Program, Joint Genome Institute, 2800 Mitchell Dr, Walnut Creek, CA, USA. Correspondence should be addressed to A.P. (apati@1bl.gov).

2 Present address: Department of Genetics and Pathology, Uppsala University, SE-751 85 Uppsala, Sweden.

We present GenePRIMP (Gene Prediction IMprovement Pipeline, http://geneprimp.jgipsf.org), a computational process that performs evidence-based evaluation of gene models in prokaryotic genomes and reports anomalies including inconsistent start sites, missed genes, and split genes. We show that manual curation of gene models using the anomaly reports generated by GenePRIMP improves their quality and demonstrate the applicability of GenePRIMP in improving finishing quality and comparing different genome sequencing and annotation technologies.

More than 1000 microbial genomes have been completely sequenced to date ${ }^{1}$. The increasing number of sequencing projects driven by high-throughput sequencing technologies has further underscored the importance of computational methods in annotating and mining genomic data. For any genome, gene finding is the key step to understanding the biochemistry, physiology, and ecology of the organism. Gene finding relies heavily on computational methods and very few sequencing projects are complemented by the experimental verification of computationally predicted genes through functional genomics experiments or mapping of $\mathrm{N}$-terminal sequences $^{2,3}$. Together with multiple sequencing technologies, multiple gene finders, and somewhat imprecise standards for the identification of genes, this can result in different researchers arriving at substantially varying gene models for the same organism ${ }^{4}$ (Fig. 1, Table 1). Consequently, higher standards of accuracy are required for computational gene prediction tools.

The most popular gene finders are $a b$ initio and work by statistically profiling protein coding, intergenic, and boundary regions using a variety of classifiers. While most ab initio gene callers boast an average accuracy of $90 \%$ or better ${ }^{5-7}$, accuracy can be compromised by many factors such as genomic islands of differing GC content, pseudogenes, and genes with programmed or artificial frameshifts, leading to sizeable variability between their gene model predictions. To improve gene models generated by ab initio predictions, some tools include heuristics and post-processing steps such as overlap removal, translation initiation site adjustment, and frameshift detection ${ }^{8,9}$, while others rely on the presence of sequenced close relatives $^{10}$ or experimental evidence ${ }^{11,12}$. However, many of these post-processing tools have been tested only on metazoan genomes and use criteria that are not applicable to prokaryotes, and/or are too slow or expensive to perform on a large number of microbial genomes.

To overcome the aforesaid limitations of ab initio gene prediction methods, and to address the problem of large variation among their gene models, we have devised GenePRIMP; a computational evidence-based post-processing pipeline that identifies erroneously predicted 
genes. Manual correction of GenePRIMP-reported genes results in a standardized output gene complement for an organism (sequence) irrespective of the method used for initial gene predictions (Fig. 1) [to what extent is manual correction needed in the GenePRIMP pipeline and how can you ensure that this manual correction will be standardized - do you mean that the corrections found with GenePRIMP will then have to be manually added to the list people are working with? The GenePRIMP report only contains the list of problems in gene definitions. These problems need to be corrected manually by the curator. Working with the GenePRIMPreport as a guide, everyone will make more or less the same corrections.]. Other applications of GenePRIMP include benchmarking of ab initio gene callers, improvement of finishing quality, detection of frameshifts in sequences generated by various technologies, and application to fungal and eukaryotic genomes with minor changes in the associated heuristics (Methods).

A typical GenePRIMP report includes seven types of anomalies, namely: short genes, long genes, unique genes, dubious genes, broken genes, interrupted genes, and putative missed genes (Fig. 2), identified from the alignment of a gene or intergenic region to its homologs. While short and long genes have anomalous start sites, broken and interrupted genes are parts of the same gene called as multiple genes. Unique/dubious genes, which have no hits to known proteins, may reveal a perfectly good gene in a different frame; such hits are included in the list of putative missed genes when examined together with the bounding intergenic regions by BLASTx. Alternatively, they may be experimentally verifiable novel genes. Broken genes might indicate the presence of a pseudogene, a programmed frameshift that does not render the gene non-functional, or a frameshift due to sequencing artifacts (for example base calling errors in homopolymer regions). GenePRIMP ensures that fusion gene components are not mislabeled as frameshift-induced broken genes by comparing against a database of fusion genes ${ }^{13}$. Joining of said frameshift fragments and subsequent tagging of genes is at the sole discretion of the curator.

The protocols captured in GenePRIMP are a result of the standardization of operating procedures used in the DOE-JGI in the manual curation of over 300 genomes $(>100,000$ genes), coming from multiple sequencing centers, over a period of 3 years. Over 194 genomes $(>400$ contigs, including permanent drafts) have been processed by GenePRIMP followed by manual curation (Supplementary Data 1). On average, about $10 \%$ of the genes in a given genome are modified by manual curation, but this percentage varies between $3 \%$ and $20 \%$ depending on the properties of the genome and the gene finder software used. With the current version of GenePRIMP, approximately $85 \%$ of all reported short genes are manually extended (short genes can only be extended with evidence when there is space on the 5 ' end for extension), $70 \%$ of all reported long genes are manually truncated, and $100 \%$ of reported broken genes as well as $31 \%$ of reported interrupted genes are manually joined. We have not shown statistics for putative missed genes because some of these intergenic regions with hits are combined with short genes during extension. We find that the numbers of short, long, unique, and total reported anomalies are positively correlated with genome size $\left(\mathrm{R}^{2}=0.66,0.65,0.38,0.407\right.$, respectively), but no correlation of anomalies is observed with genome GC content $\left(\mathrm{R}^{2}=0.0007,0.1038,0.0004\right.$, 0.0134, 0.0076, 0.00006, 0.0023 for short, long, unique, broken, interrupted, missed genes, and total number of reported anomalies, respectively). We observe positive correlations between some anomaly types: a moderately high correlation between the numbers of short and long genes, likely arising from imprecise detection of ribosome-binding sites by ab initio gene finders (Supplementary Fig. 1).

We used GenePRIMP to compare the accuracy of five popular gene finders: Prodigal ${ }^{5}$, GeneMark $^{6}$, Glimmer3 ${ }^{7}$, RAST $^{14}$, and AMIGene ${ }^{15}$ by evaluating their gene calls for two 
genomes: the bacterium Mycobacterium sp. Spyr1 (Myco) and the archaeon Methanosphaerula palustris E1-9c (Meth), selected because of the high number of modifications made to their gene models during manual curation (See Supplementary Data 2-5 for gene definitions in these two genomes before and after manual curation). Comparisons were based on the number of anomalies of each type detected by GenePRIMP (Table 1). Results of automated gene finding for these two genomes vary wildly among the different tools and pipelines. Notably in Meth, Glimmer3 predicted the most unique genes (522); 226 of these were not called by any other gene caller and only 38 genes were predicted by all others (Supplementary Fig. 2). Glimmer3 identified 515 more genes (18\%) in Meth than did Prodigal, which identified the lowest number of genes; many of these additional genes were among the 522 unique genes predicted by Glimmer3. We observed considerable variation in the gene-finders' identification of translation initiation sites. Glimmer3, GeneMark, and RAST show a tendency to predict genes shorter than their homologs, whereas AMIGene calls more long genes than any of the others. The occurrence of missed genes and predicted genes that are longer or shorter than their homologs reflects the current limitations of automated gene finding in microbial genomes. The number of broken and interrupted genes identified in the gene calls indicates the sensitivity of the respective gene caller. Higher numbers attest to the greater ability of that gene caller to identify shorter regions of CDSs, including small fragments in highly degraded pseudogenes. This facilitates the correction of sequencing artifacts, pseudogenes, and genes with unusual translational features.

After manual curation for a given genome using the GenePRIMP report, the final gene model complements are very similar (Fig. 1) even though different gene callers are used. Data on genes from Meth, with no closely related sequenced genomes, demonstrate that the accuracy of GenePRIMP does not rely heavily on the presence of closely related species. We examined the 2584 genes that have matching stop positions and differing start positions, and the 1669 genes that have both matching start positions and matching stop positions, among gene calls of three gene callers: Prodigal, GeneMark, and RAST. These are further examined in Supplementary Fig. 3. [is it necessary to detail these results in the main text - you could just refer to SI fig. 3. I have changed the text accordingly.] Since Prodigal is part of the regular microbial annotation pipeline at the DOE-JGI, we evaluated GenePRIMP's handling of the 235 genes that were only called by Prodigal ( $8 \%$ of the Prodigal total). Hypothesizing that most of those 235 genes are good predictions, we deduced that GenePRIMP should report them as missed genes in the RAST and GeneMark gene calls. From Fig. 1, we observe that GenePRIMP correctly identified 93\% of the 235 genes predicted by Prodigal but missed by RAST or GeneMark or both. Examination of the remaining 7\% revealed that GenePRIMP did not discover them because of the presence of spurious genes on the opposite strands.

GenePRIMP is available as a web-based application (Supplementary Fig. 4). The compute time for any genome is dominated by the time taken to perform Blast alignments; a 4 $\mathrm{Mb}$ genome typically runs in about 2 hours on a computer with $162300 \mathrm{MHz}$ CPUs and 64 GB of shared memory. Current and future directions for GenePRIMP include automatic correction of GenePRIMP-reported anomalies to the extent possible, as well as automatic identification of putative frameshifts and pseudogenes. GenePRIMP is a significant step towards automation and standardization of the long-standing process of gene finding and manual curation. As such, it is also following the principles of standardization of the Genomics Standards Consortium and further development will factor in the Consortium's recommendations.

\section{METHODS}


Methods and any associated references are available in the online version of the paper at http://www.nature.com/naturemethods/.

Note: Supplementary information is available on the Nature Methods website.

\section{Acknowledgements}

We would like to gratefully acknowledge the help and support of I. Anderson and K. Mavromatis from the Genome Biology Program, Xueling Zhao from DOE JGI, and V. Markowitz from the Biological Data Management and Technology Center. This work was performed under the auspices of the US Department of Energy's Office of Science, Biological and Environmental Research Program, and by the University of California, Lawrence Berkeley National Laboratory under contract No. DE-AC02-05CH11231, Lawrence Livermore National Laboratory under Contract No. DE-AC52-07NA27344, and Los Alamos National Laboratory under contract No. DE-AC02-06NA25396.

\section{AUTHOR CONTRIBUTIONS}

N.N.I. and N.C.K. conceived the initial approach. N.N.I. and A.P. designed the system. A.P. implemented the GenePRIMP code base and web portal. S.D.H. contributed to the development of the web portal. N.N.I., N.M., G.O., and A.L. did the manual curation for the genomes and contributed to testing and validation.

\section{COMPETING INTERESTS STATEMENT}

The authors declare that they have no competing financial interests.

\section{References}

1. Benson, D.A., Karsch-Mizrachi, I., Lipman, D.J., Ostell, J. \& Sayers, E.W. Nucleic Acids Res. 38, D46-D51 (2010).

2. Ishino, Y., Okada, H., Ikeuchi, M. \& Taniguchi, H. Proteomics. 7, 4053-4065 (2007).

3. Smollett, K.L. et al. Microbiology 155, 186-197 (2009).

4. Kyrpides, N.C. Nat. Biotechnology 27, 627 -632 (2009)

5. Hyatt, Doug. et al. BMC Bioinformatics, In press.

6. Besemer, J., Lomsadze, A. \& Borodovsky, M. Nucleic Acids Res. 29, 2607-2618 (2001).

7. Delcher, A.L., Bratke, K.A., Powers, E.C. \& Salzberg, S.L. Bioinformatics 23, 673-679 (2007).

8. Zhu, H.Q., Hu, G.Q., Quyang, Z.Q., Wang, J. \& She, Z.S. Bioinformatics 20, 3308-3317 (2008).

9. Tech, M. \& Meinicke, P. BMC Bioinformatics 7:121, (2006).

10. Yu, G.X. et al. Nucleic Acids Res. 35, 3953-3962 (2007).

11. Nagy, A. et al. BMC Bioinformatics 9:353 (2008).

12. Castellanaa, N.E. et al. PNAS 105, 21034-21038 (2008).

13. Markowitz V.M., et al. Nucleic Acids Res, 38, D382-D390 (2010).

14. Aziz, R.K. et al. BMC Genomics 9:75 (2008).

15. Bocs, S., Cruveiller, S., Vallenet, D., Nuel, G., \& Medigue, C. Nucleic Acids Res. 31, 3723-3726 (2003). 


\section{FIGURE LEGENDS}

Figure 1 GenePRIMP analysis of gene calls in Methanosphaerula palustris E1-9c (Meth) by three gene callers.. Using GenePRIMP, we analyzed the 2,819-2,584=235 genes in Prodigal that were not common to all of the three gene callers. Of the 121 genes predicted only by Prodigal and GeneMark, GenePRIMP reported 118 as putative missed genes among the RAST gene calls. Likewise, of the 26 genes called only by Prodigal and RAST, GenePRIMP identified 23 as putative missed genes among the GeneMark gene calls. Lastly, of the 88 genes called only by Prodigal, GenePRIMP identified 76 as putative missed genes in both the GeneMark and RAST gene calls. 7 of these 88 genes were found in neither GeneMark- nor RAST-generated gene calls. For 83 of the 88 genes (corresponding cells are highlighted in yellow), GenePRIMP decisions matched for both GeneMark- and RAST-generated gene calls. For only 5 of these 88 genes, GenePRIMP decisions disagreed between GeneMark- and RAST-generated gene calls. The disagreement was due to the presence of spurious genes on the opposite strands in the same intergenic region for one of the two gene callers. Similar results were observed for Glimmer3 and Amigene (data not shown). Please do not repeat the numbers already stated in the figure, but explain what the yellow color in the $3^{\text {rd }}$ column means. Since we have pruned the descriptions in the text so much, the existing figure legends are necessary for the explanations to flow.

Figure 2 The GenePRIMP processing pipeline. (a) Detection of gene call anomalies by GenePRIMP. (b) Blast alignments of short, long, broken, and interrupted genes. A query gene is shown aligned against its homologs in NCBI's nr database for each of the indicated classes. All sequences are shown $5^{\prime}$ to $3^{\prime}$ from left to right. [this is already explained in the main text. The exact definitions of broken and interrupted genes are not included in the main text. Also, short and long genes are explained in greater detail in this legend. Since these descriptions are key to understanding the anomalies, I would prefer to keep this part.] 
Table 1 Comparison of five gene calling applications.

\begin{tabular}{|c|c|c|c|c|c|c|c|c|c|c|}
\hline & \multicolumn{5}{|c|}{$\begin{array}{l}\text { Mycobacterium sp. Spyr1 } \\
\text { GC } \%=67.9, \text { Size }=6 \mathrm{Mb}\end{array}$} & \multicolumn{5}{|c|}{$\begin{array}{l}\text { Methanosphaerula palustris E1-9c } \\
\mathrm{GC} \%=55.35, \text { Size }=2.9 \mathrm{Mb}\end{array}$} \\
\hline & $\begin{array}{l}\text { GeneM } \\
\text { ark }\end{array}$ & $\begin{array}{l}\text { Glimm } \\
\text { er3 }\end{array}$ & $\begin{array}{l}\text { Prodi } \\
\text { gal }\end{array}$ & RAST & $\begin{array}{l}\text { AMI } \\
\text { Gene }\end{array}$ & $\begin{array}{l}\text { Gene } \\
\text { Mark }\end{array}$ & $\begin{array}{l}\text { Glimm } \\
\text { er3 }\end{array}$ & $\begin{array}{l}\text { Prodig } \\
\text { al }\end{array}$ & RAST & $\begin{array}{l}\text { AMI } \\
\text { Gene }\end{array}$ \\
\hline CDSs & 5553 & 5395 & 5296 & 5304 & 4888 & 2974 & 3334 & 2819 & 2940 & 3177 \\
\hline Short genes & 482 & 398 & 267 & 672 & 79 & 235 & 230 & 202 & 420 & 115 \\
\hline Long genes & 83 & 53 & 62 & 34 & 992 & 46 & 59 & 60 & 47 & 294 \\
\hline $\begin{array}{l}\text { \% CDSs w/ } \\
\text { anomalous } \\
\text { starts (short + } \\
\text { long) }\end{array}$ & 10.17 & 8.36 & 6.21 & 13.31 & 21.74 & 9.49 & 8.69 & 9.61 & 15.9 & 12.87 \\
\hline Missed genes & $\begin{array}{c}607 \\
(10.93 \\
\%)\end{array}$ & $\begin{array}{r}569 \\
(10.54 \\
\%)\end{array}$ & $\begin{array}{r}451 \\
(8.51 \\
\%)\end{array}$ & $\begin{array}{c}735 \\
(13.9 \\
\%)\end{array}$ & $\begin{array}{c}658 \\
(13.46 \\
\%)\end{array}$ & $\begin{array}{r}196 \\
(6.59 \\
\%)\end{array}$ & $\begin{array}{c}206 \\
(6.18 \% \\
)\end{array}$ & $\begin{array}{r}167 \\
(5.92 \% \\
)\end{array}$ & $\begin{array}{r}305 \\
(10.4 \% \\
)\end{array}$ & $\begin{array}{r}106 \\
(3.33 \\
\%)\end{array}$ \\
\hline Unique genes & 67 & 118 & 23 & 206 & 99 & 190 & 522 & 103 & 229 & 277 \\
\hline Dubious genes & 11 & 0 & 2 & 0 & 10 & 25 & 0 & 2 & 1 & 8 \\
\hline Broken genes & 30 & 33 & 27 & 22 & 34 & 41 & 50 & 27 & 29 & 71 \\
\hline $\begin{array}{l}\text { Interrupted } \\
\text { genes }\end{array}$ & 51 & 62 & 48 & 60 & 53 & 23 & 36 & 32 & 31 & 60 \\
\hline
\end{tabular}




\section{Online Methods}

\section{All text needs to be run on and only one level of subheadings are allowed. Done.}

\section{The GenePRIMP algorithm}

The flowchart for the high-level GenePRIMP algorithm is diagrammed in Supplementary Fig. 5. In summary, for each contig in the input file, all features are parsed and stored. PILER-CR, a CRISPR finder, is then run on the contig sequence and any CRISPRs found are integrated into the feature list. Any overlaps between features are computed and an overlap report generated. Protein sequences for genes are aligned to a low-complexity filtered Blast database using the parameters '-p blastp -e 0.00001 -b 15 -v 15 -a 16'. Genes without hits are aligned again using Blast with a relaxed cutoff with parameters '-p blastp -e 10 -b 15 -v 15 -F F -a 16'. Genes without hits are classified as unique. Unique genes that are shorter than 30 amino acids are classified as dubious. Genes with hits from both rounds of Blast are filtered to removeintersecting high-scoring pairs (HSPs) constituting bad alignments, hits to eukaryotes, and hits to the draft genome of the same subject organism. Filtered alignments are used for the classification into long/short/broken/interrupted and potential long/short genes. The exact algorithms for identifying long, short, broken, and interrupted genes are described below. Intergenic regions are computed that include unique and dubious genes and boundary adjustments for short and long genes. These adjusted intergenic regions are aligned to the filtered Blast database with the parameters '-p blastx -e 0.1 -b $10-\mathrm{v} 10-\mathrm{w} 15$-a 16'. Alignments are filtered to remove hits to eukaryotes, HSPs in different frames, and hits to the draft genome of the same subject organism. Intergenic regions with reliable alignments are reported as putative missed genes. Genes that were classified as potential long/short genes are examined further. If a potential short gene and its 5' intergenic region share hits to common subject(s), the gene is confirmed as short. If a potential long gene has a promoter region that is shorter than 100 bases, it is confirmed as long.

\section{Detection of short and long genes}

Short and long genes are detected using a criterion called an alignment score $(\boldsymbol{\alpha})$. Let $\mathrm{S}_{\mathrm{Q}}$ be a query sequence aligned against homologous sequence $S_{H}$. Let $c_{q}$ and $c_{h}$ indicate the start coordinates of the alignment on $\mathrm{S}_{\mathrm{Q}}$ and $\mathrm{S}_{\mathrm{H}}$, respectively. The alignment quality score $(\alpha)$ is then defined as:

$$
\alpha=\frac{c_{q}-c_{h}}{c_{q}+c_{h}} .
$$

While the difference between the start sites, $\mathrm{c}_{\mathrm{q}}-\mathrm{c}_{\mathrm{h}}$, is necessary to determine whether a query gene might be long, short, or good, it is not sufficient. Supplementary Figs. 6(a) and 6(b) illustrate two candidates for long genes. Observe that for the same difference in starts of alignment $\left(\mathrm{c}_{\mathrm{q}}-\mathrm{c}_{\mathrm{h}}=28\right)$, whether a gene is long or not also depends on where the alignment starts on the subject and the query. The same phenomenon for short genes is illustrated in Supplementary Figs. 6(c) and 6(d). Therefore, instead of making decisions based simply on the difference between the start sites, $\mathrm{c}_{\mathrm{q}}-\mathrm{c}_{\mathrm{h}}$, GenePRIMP uses the alignment quality score that represents the disparity in the start positions as a fraction of the actual distance of the start 
positions from the beginning of their respective sequences (Supplementary Fig. 7). To obtain the cut-off values shown, we plotted the distribution of mean and median values of $\alpha$ for genes from five genomes that had been manually curated and identified as long, short, or matching genes (Supplementary Figs. 8 and 9). The resultant mean and median alignment scores were also calculated for each gene type (Supplementary Table 1).

\section{Detection of broken genes}

Two genes that are called adjacent to one another are identified as a broken gene if they satisfy all the following conditions: they have the same orientation; they have at least two common homologs; their hits are to consecutive regions on the same homolog, not to the same regions; their shared homologs are approximately of the same length; when the sequence from the beginning of the first gene to the end of the second gene is aligned using BlastX, at least one hit is among those observed for the two individual genes; the hits for the combined region are not fusion genes as recognized by the fusion genes database in IMG.

\section{Detection of interrupted genes}

Two genes are identified as a gene interrupted by a transposase(s) when all the following conditions are satisfied: they have the same orientation; they have at least one common homolog; each of them has hits to at least 4 subjects; the homologs are approximately of the same length.

\section{Application to fungal and eukaryotic genomes}

With minor changes, GenePRIMP can be applied to fungal/eukaryotic genomes. Hits from both BlastP and BlastX for genes and intergenic regions, respectively, are filtered to exclude hits to eukaryotic genomes. Additionally, these filters as well as other filters in various stages of the GenePRIMP algorithm employ various heuristics based on the number of hits to eukaryotic genomes present. Adjustment of these filters and heuristics leads to an anomaly-detection framework for eukaryotic and fungal genomes.

\section{Detection of frameshifts}

Putative frameshifts can be detected from the following scenarios of anomalies: when a gene is short on the 5' end or on the 3' end and the remaining fragment of the gene is present in the adjoining intergenic region in a frame different from that of the gene; when a missed gene is inserted with one or more frameshifts; when two or more genes are determined as part of the broken gene and are joined with one or more frameshifts; convergent overlaps.

These methods of frameshifts detection have been implemented in an automated manner in the next version of GenePRIMP and are currently being tested in-house. With the current version of GenePRIMP, these scenarios have to be manually analyzed to detect frameshifts.

\section{Detection of pseudogenes}

As with frameshifts, pseudogenes can be detected by analyzing specific anomaly scenarios. The following anomaly scenarios suggest the presence of candidate pseudogenes: 1. A gene short 
either on the $5^{\prime}$ end or the $3^{\prime}$ end, which cannot be extended either due to the absence of sufficient intergenic space on the said side, or due to the absence of the correct sequence in the available intergenic region. Such a gene might miss important functional domains and become non-functional. While the "pseudo" status for such a gene can be manually determined with relatively high confidence, the automatic detection of "pseudo" status for such a gene might be possible through the analysis of its alignment to homologs. 2. A short gene that has been extended on either the 3' or the 5' end, or a missed gene that has been inserted with one or more frameshifts. In the case of two or more frameshifts, loss of function is definite and the gene can be automatically tagged as a pseudogene. In the case where only one frameshift is present, it might be because of a ribosomal slippage. This scenario requires manual analysis to confirm pseudo status. 3. A short gene that has been extended on either the 3' or the 5' end, or a missed gene that has been inserted with one or more stop codons or multiple frameshifts or stop codons. The presence of multiple frameshifts/stop codons is once again a positive indicator for a pseudogene. 4. A broken gene that is joined with multiple frameshifts/stop codons can also indicate a putative pseudogene.

These methods of pseudogene detection have been implemented in an automated manner in the next version of GenePRIMP and are currently being tested in-house. With the current version of GenePRIMP, these scenarios have to be manually analyzed to detect pseudogenes. 


\section{LIST OF SUPPLEMENTARY ITEMS}

\begin{tabular}{|c|c|}
\hline Supplementary File & Title \\
\hline Supplementary Figure 1 & Correlations between anomaly types. \\
\hline Supplementary Figure 2 & $\begin{array}{l}\text { Analysis of unique genes identified by } \\
\text { Glimmer3 and RAST. }\end{array}$ \\
\hline Supplementary Figure 3 & $\begin{array}{l}\text { Comparison of GenePRIMP anomaly reports } \\
\text { with long/short/unique gene calls. }\end{array}$ \\
\hline Supplementary Figure 4 & $\begin{array}{l}\text { Collage showing screenshots of web pages in } \\
\text { the GenePRIMP portal. }\end{array}$ \\
\hline Supplementary Figure 5 & Process flow in GenePRIMP. \\
\hline Supplementary Figure 6 & $\begin{array}{l}\text { Identification of long and short genes from } \\
\text { alignments. }\end{array}$ \\
\hline Supplementary Figure 7 & $\begin{array}{l}\text { Identification of long, short, and matching } \\
\text { genes based on average and median alignment } \\
\text { scores }(\alpha) \text {. }\end{array}$ \\
\hline Supplementary Figure 8 & $\begin{array}{l}\text { Distribution of mean alignment scores }(\alpha) \text { in } \\
\text { short, matching, and long genes. }\end{array}$ \\
\hline Supplementary Figure 9 & $\begin{array}{l}\text { Distribution of median alignment scores }(\alpha) \text { in } \\
\text { short, matching, and long genes }\end{array}$ \\
\hline Supplementary Table 1 & $\begin{array}{l}\text { Alignment scores }(\alpha) \text { for short, matching, and } \\
\text { long genes. }\end{array}$ \\
\hline Supplementary Data 1 & $\begin{array}{l}\text { Statistics of all public contigs processed by } \\
\text { GenePRIMP }\end{array}$ \\
\hline Supplementary Data 2 & $\begin{array}{l}\text { Gene models in Methanosphaerula palustris } \\
\text { E1-9c before manual curation }\end{array}$ \\
\hline Supplementary Data 3 & $\begin{array}{l}\text { Gene models in Methanosphaerula palustris } \\
\text { E1-9c after manual curation }\end{array}$ \\
\hline Supplementary Data 4 & $\begin{array}{l}\text { Gene models in Mycobacterium sp. Spyr1 } \\
\text { before manual curation }\end{array}$ \\
\hline Supplementary Data 5 & $\begin{array}{l}\text { Gene models in Mycobacterium sp. Spyr1 after } \\
\text { manual curation }\end{array}$ \\
\hline
\end{tabular}

\section{Editorial Summary}

This computational process evaluates gene models in prokaryotic genomes, independent of the gene finder used, and reports anomalies that can be used to improve the quality of gene models through manual curation. 


\section{Supplementary Figure 1: Correlations between anomaly types}

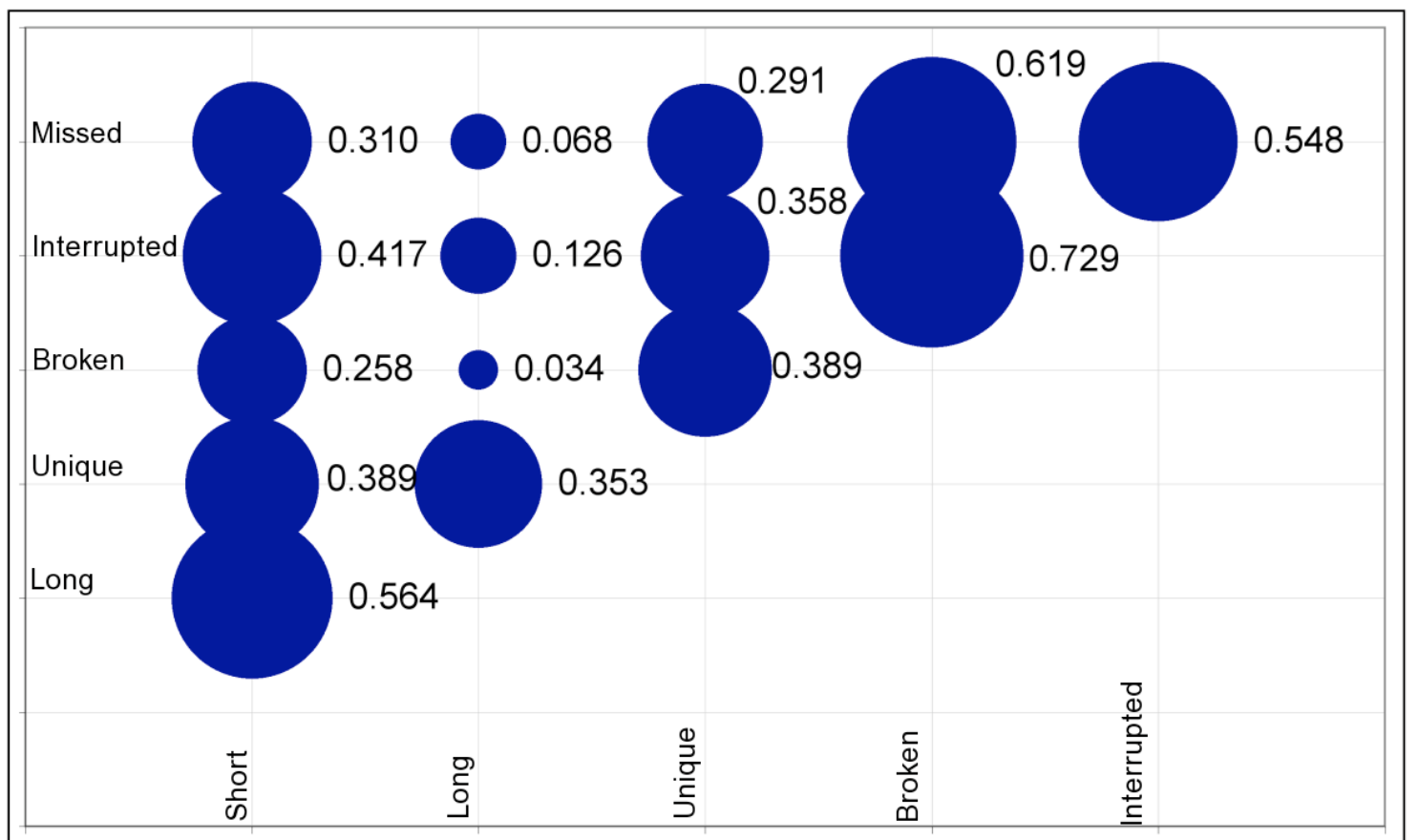

Correlations between anomaly types. Based on all contigs that were manually curated, some types of anomalies were found to be positively correlated with others. The number of missed genes shows the strongest positive correlation with the number of broken, interrupted and short genes, since BLASTx searches of the intergenic regions identified not only missed genes per se, but also missed fragments of predicted genes, such as missed $\mathrm{N}$-terminal sequences of short genes or missed fragments of broken genes. On the other hand, since unique genes often mask a missed gene in a different translation frame, positive correlation between the number of missed and unique genes is not entirely unexpected. Positive correlation between the number of short, interrupted and broken genes likely reflects the fact that these 3 categories include a large number of pseudogenes that may have been generated by gene truncation, disruption of translation frame by frameshifts and/or stop codons or interruption of genes by transposable elements. 


\section{Supplementary Figure 2: Analysis of unique genes identified by Glimmer3 and RAST}

\begin{tabular}{|l|l|l|l|l|l|}
\hline GeneMark & $\begin{array}{l}\text { RAST in } \\
\text { case of Meth, } \\
\text { Glimmer3 in } \\
\text { case of Myco }\end{array}$ & Prodigal & AMIGene & $\begin{array}{l}\text { Unique genes } \\
\text { predicted by } \\
\text { Glimmer3 in } \\
\text { Meth }\end{array}$ & $\begin{array}{l}\text { Unique } \\
\text { genes } \\
\text { predicted } \\
\text { by RAST } \\
\text { in Myco }\end{array}$ \\
\hline & & & & 38 & 226 \\
\hline & & & 3 & 62 \\
\hline & & & 0 & 5 \\
\hline & & & 0 & 2 \\
\hline & & & 104 & 56 \\
\hline & & & 57 & 22 \\
\hline & & & 1 & 5 \\
\hline & & & 0 & 5 \\
\hline & & & 0 & 23 \\
\hline & & & 0 & 11 \\
\hline & & & 0 & 4 \\
\hline & & & 0 & 13 \\
\hline & & & 0 & 18 \\
\hline & & & 3 & 22 \\
\hline & & & 0 & 10 \\
\hline Total: & & & 206 & 38 \\
\hline
\end{tabular}

Analysis of unique genes identified by Glimmer3 and RAST. While Glimmer3 identified the most unique genes in Methanosphaerula palustris E1-9c (Meth), RAST identified the most unique genes in Mycobacterium sp. Spyr1 (Myco). We compared these unique genes to evaluate how many were common with genes called by other gene callers for the same genomes. Red indicates absence and green indicates presence of a gene in the gene calls for a given gene caller. Glimmer3 called the highest number of unique genes in Meth (522) (See Table 1). However, only 38 of these were called by the other 4 gene callers as well. Most of the unique genes (226) were not called by any other gene caller. RAST called the highest number of unique genes in Myco (206). None of these genes were called by all 4 remaining gene callers and 38 out of the 206 genes were not predicted by any other gene caller. 104 of these 206 unique genes were predicted by Glimmer3 as well. This could be explained by the fact that Glimmer3 is part of the RAST pipeline for gene prediction. 
Supplementary Figure 3: Comparison of GenePRIMP anomaly reports with long/short/unique gene calls

EXACT MATCH

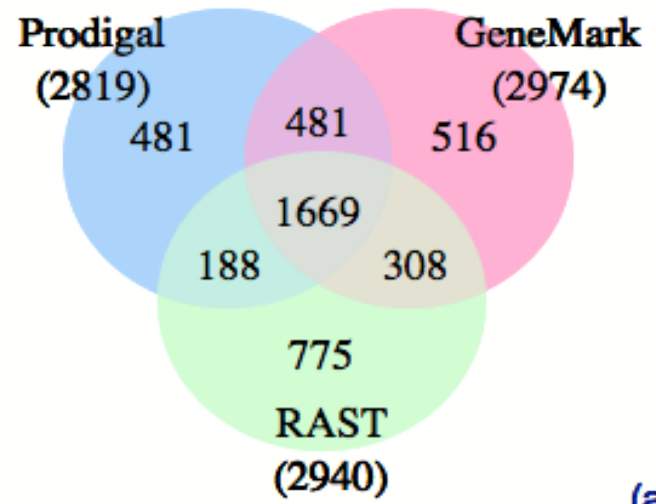

ENDS MATCH

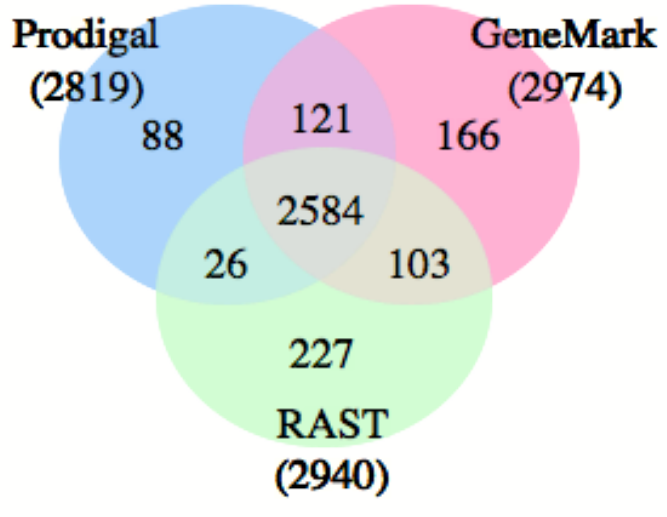

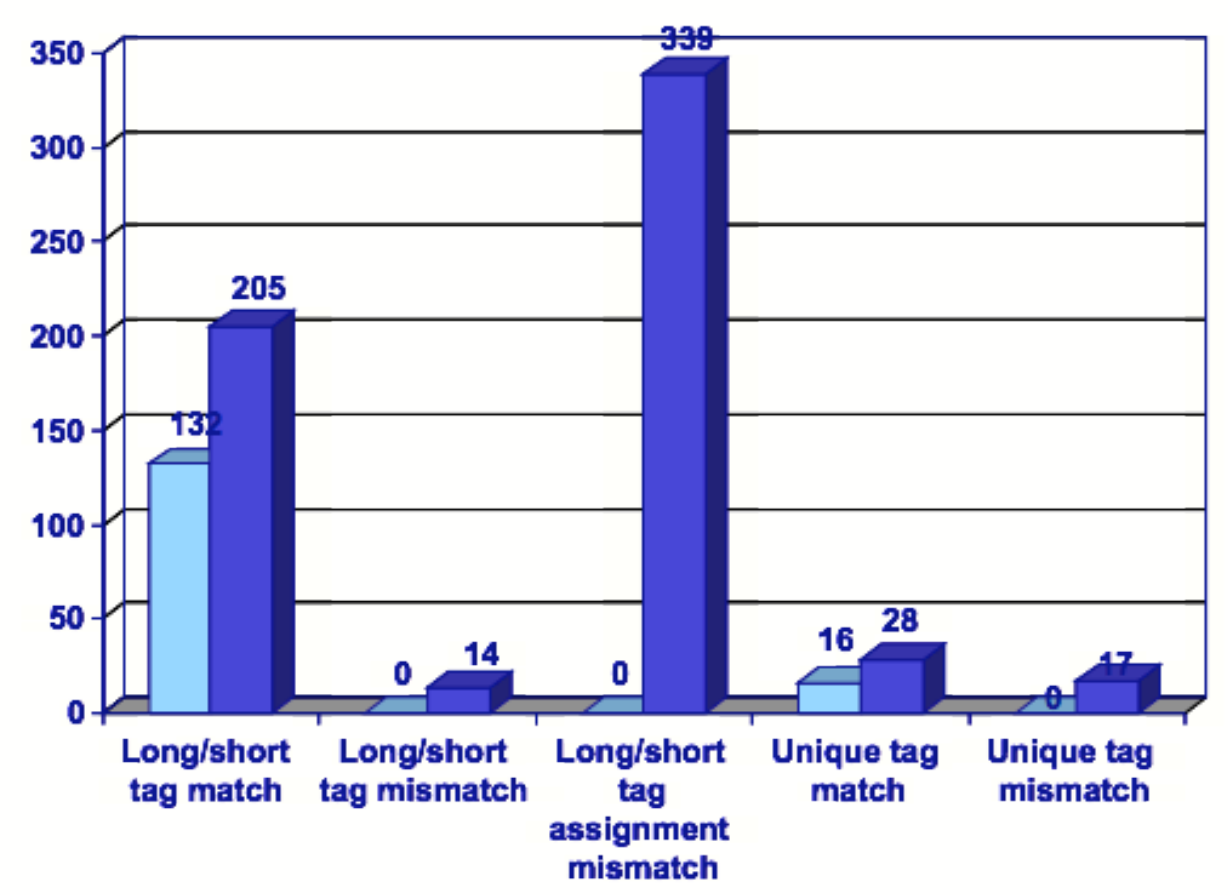

$\square 1669$ common genes $\square 2584$ genes with matching ends and varying starts

(b)

Comparison of GenePRIMP anomaly reports with long/short/unique gene calls. Gene calls generated for the archaeon Methanosphaerula palustris E1-9c by Prodigal, GeneMark, RAST, Glimmer3, and AMIGene were compared and also processed with GenePRIMP. Fig. 3(a) shows comparison of gene models predicted by Prodigal, GeneMark and RAST including comparison of exactly matching genes (EXACT MATCH, i.e., the genes that were predicted on the same strand with identical coordinates of start and stop codons) and of the genes with matching stop codons (ENDS MATCH, i.e., the genes that were predicted on the same strand with identical coordinates of the stop codon, but possibly different start codons). This figure shows that less than $60 \%$ of the genes predicted by any single gene caller are exactly matched by both other gene finders, whereas the number of the genes sharing the same stop codon is close to $90 \%$. Similar results 
were observed for Glimmer3 and AMIGene as well (not shown for clarity of presentation). Fig. 3 (b) shows distribution of anomalies among the genes predicted identically by the 3 gene finders (Prodigal, GeneMark and RAST) and among the genes sharing the same stop codon.

- Unique tag match = genes called as unique by one gene caller and called the same by all three.

- Unique tag mismatch = genes called as unique by one gene caller but not called the same by all three.

- Long/short tag match = genes called as either long or short by one gene caller and called the same by all three.

- Long/short tag/assignment mismatch = genes called as either long or short by one gene caller but not called the same by all three.

This sanity check shows that if a gene has been called short/long with an anomalous translation start site, GenePRIMP captures it as an anomaly irrespective of the gene caller whose gene definitions are the source of the anomaly. 
Supplementary Figure 4: Collage showing screenshots of web pages in the GenePRIMP portal.

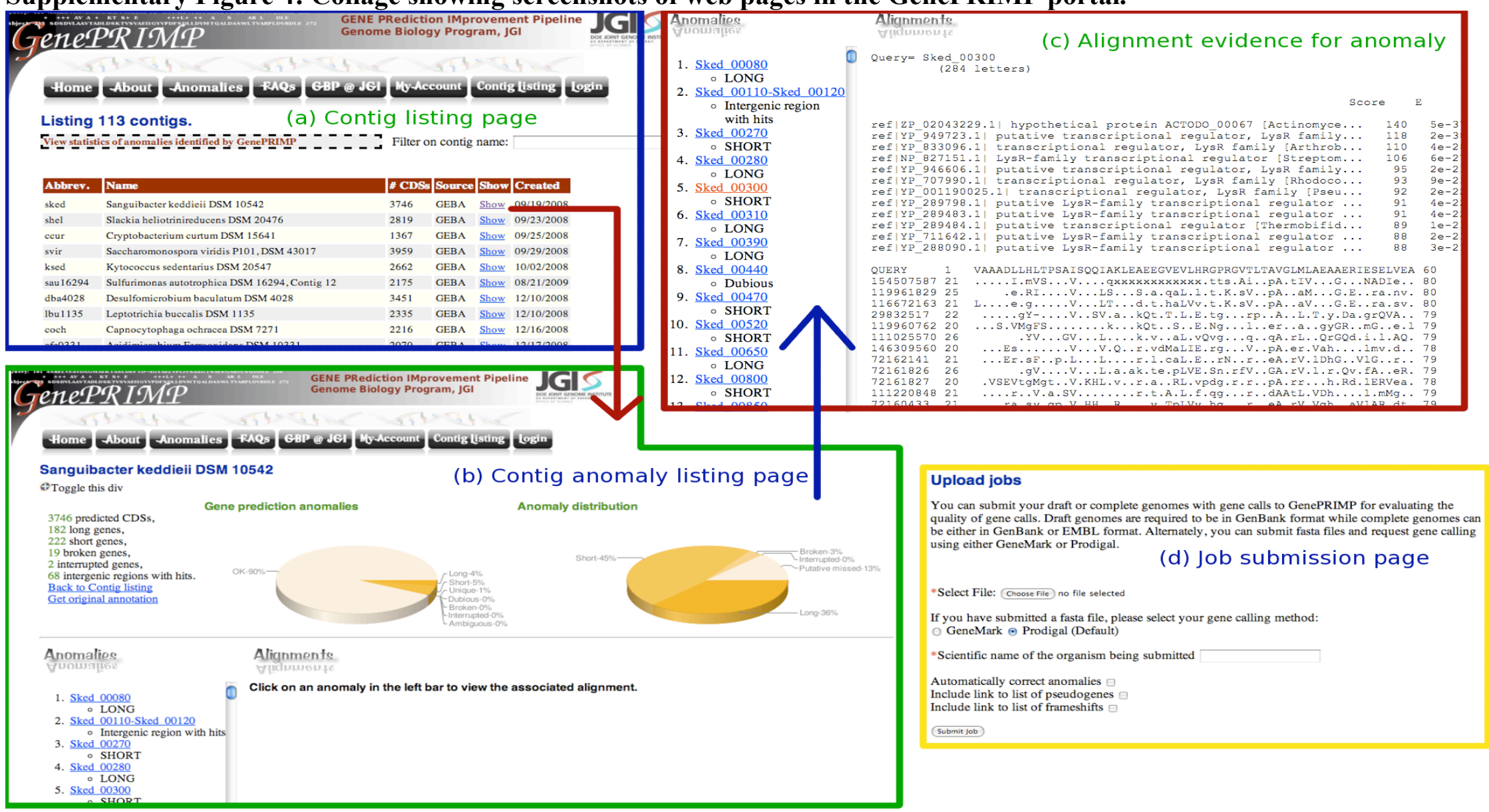

Collage showing screenshots of web pages in the GenePRIMP portal. Evaluated contigs are listed on the contig-listing page (a). From here, statistics and details of the anomalies found for any contig can be viewed by clicking on the "Show" link for that contig and navigating to the contig anomaly-listing page (b). Alignment evidence for each anomaly can be seen by clicking on that anomaly (c). GenePRIMP offers the option to register and submit contigs for processing at the web site. 
Supplementary Figure 5. Process flow in GenePRIMP

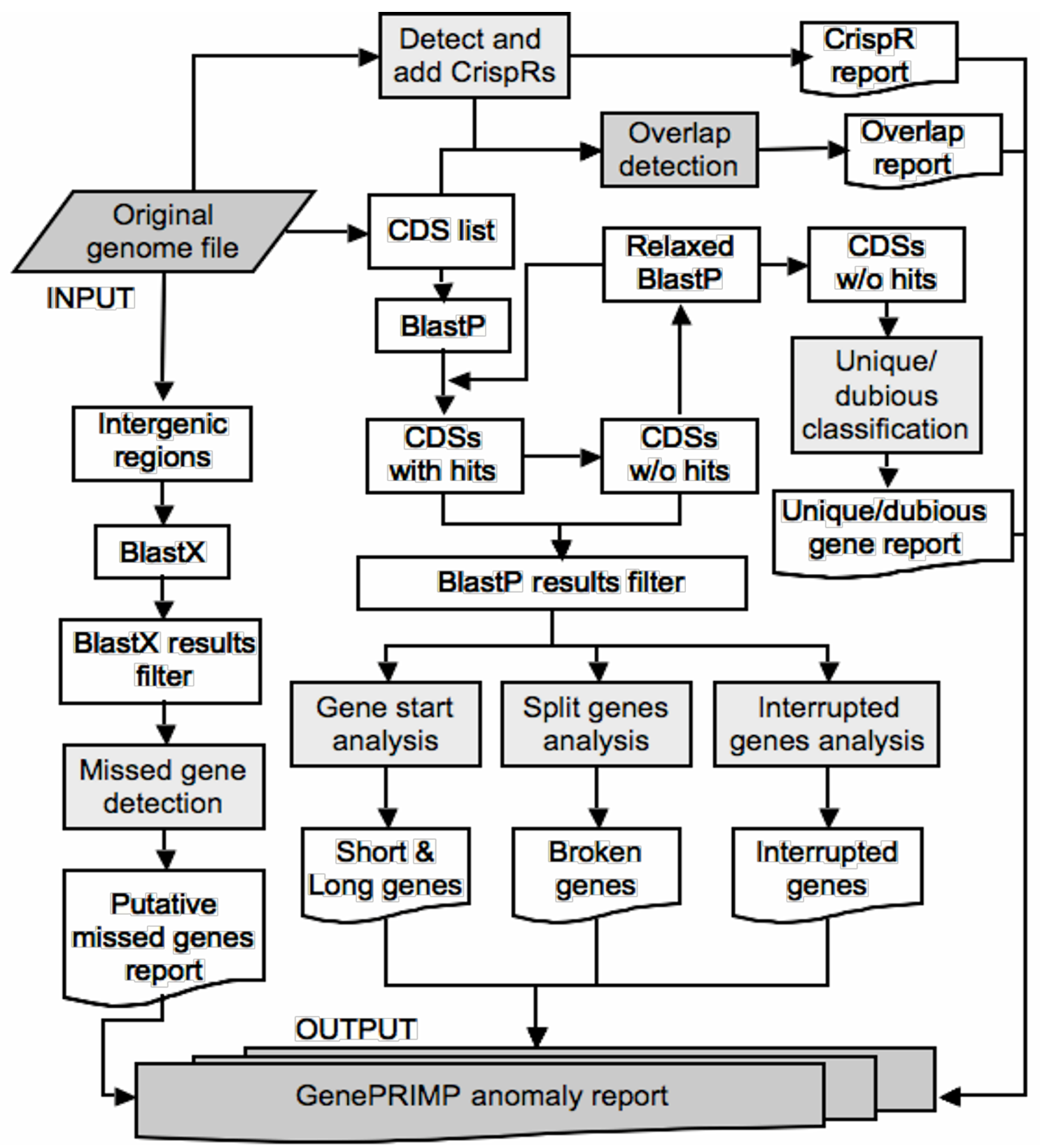

Process flow in GenePRIMP. 
Supplementary Figure 6: Identification of long and short genes from alignments

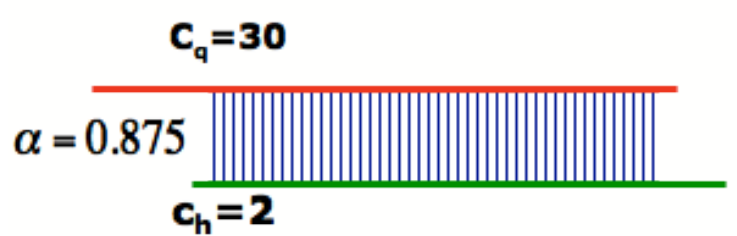

(a)

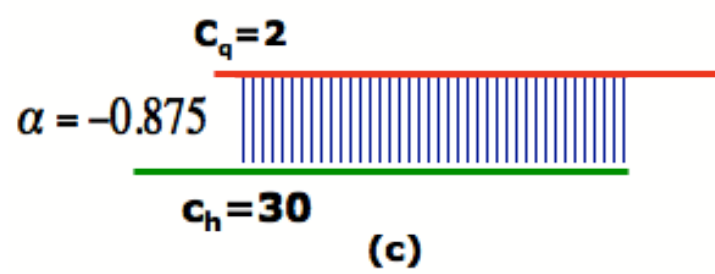

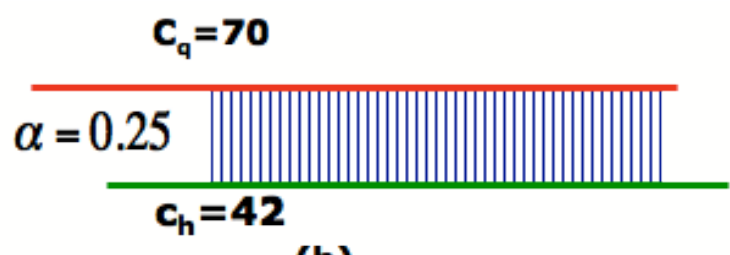

(b)

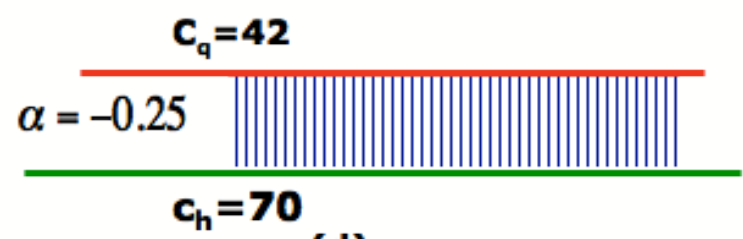

(d)

\section{Query} Homolog

Identification of long and short genes from alignments.

(a) Query gene is actually longer than the subject gene. (b) Query gene appears to be longer than the subject gene as seen from $\mathbf{c}_{\mathrm{q}}-\mathrm{c}_{\mathrm{h}}$ but is not very much longer. (c) Query gene is actually shorter than the subject gene. (d) Query gene appears to be shorter than the subject gene from $\mathrm{c}_{\mathrm{q}}-\mathrm{c}_{\mathrm{h}}$ but is not very much shorter. 
Supplementary Figure 7: Identification of long, short, and matching genes based on average and median alignment $\operatorname{scores}(\alpha)$

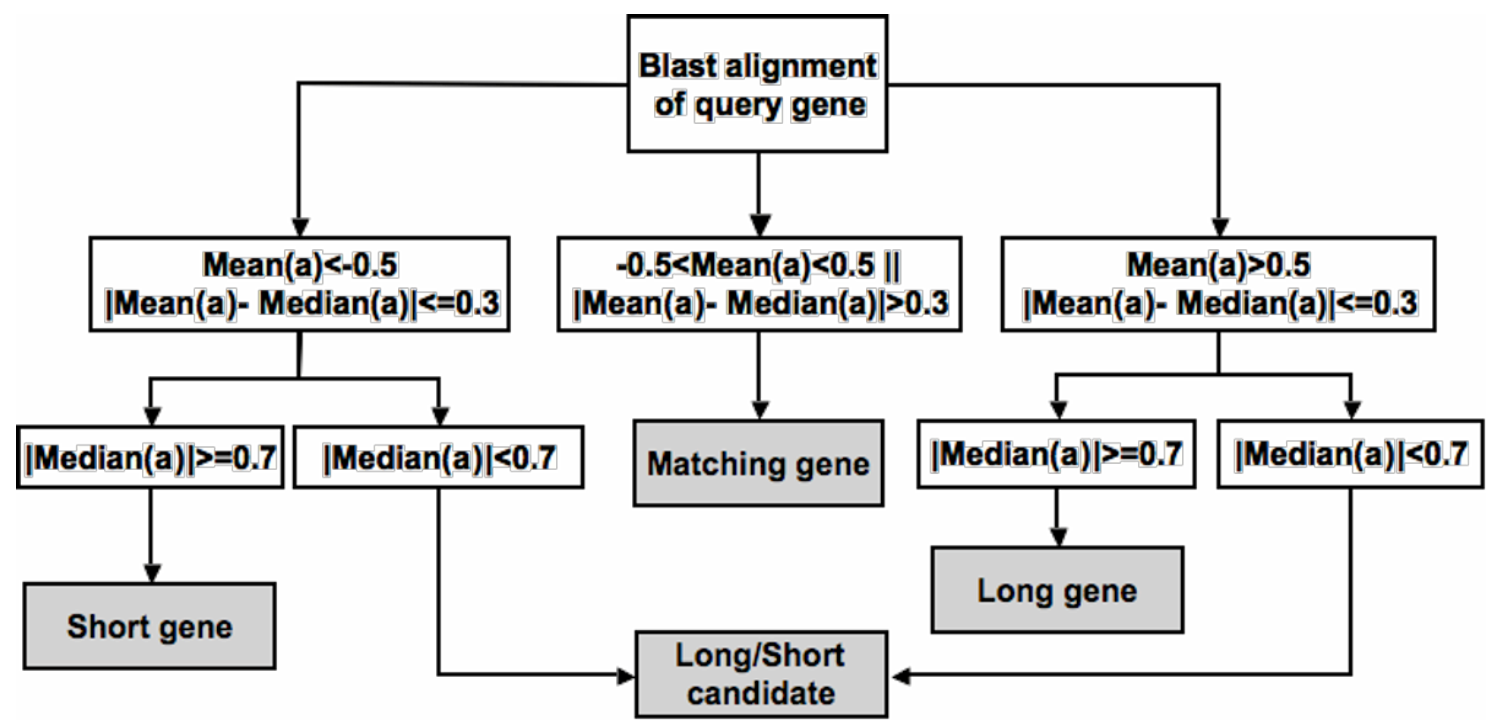

Identification of long, short, and matching genes based on average and median alignment scores $(\alpha)$. 


\section{Supplementary Figure 8: Distribution of mean alignment scores $(\alpha)$ in short,}

matching, and long genes

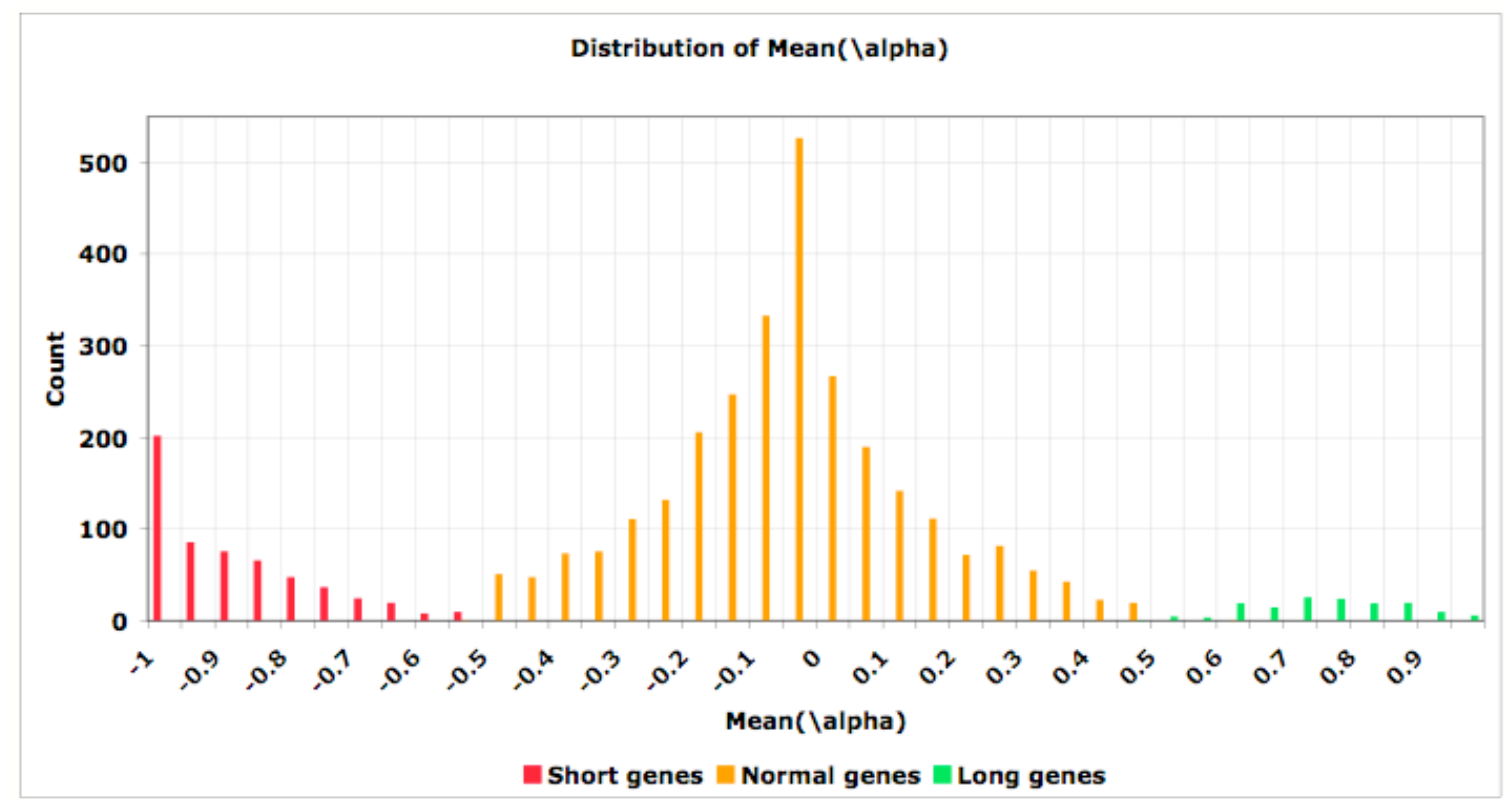

Distribution of mean alignment scores $(\alpha)$ in short, matching, and long genes. Data plotted is from gene calls made by Prodigal for five genomes with $68.3 \%, 56.4 \%, 58.65 \%, 42.83 \%$, and $65.1 \%$ GC content, respectively. 


\section{Supplementary Figure 9: Distribution of median alignment scores $(\alpha)$ in short, matching, and long genes}

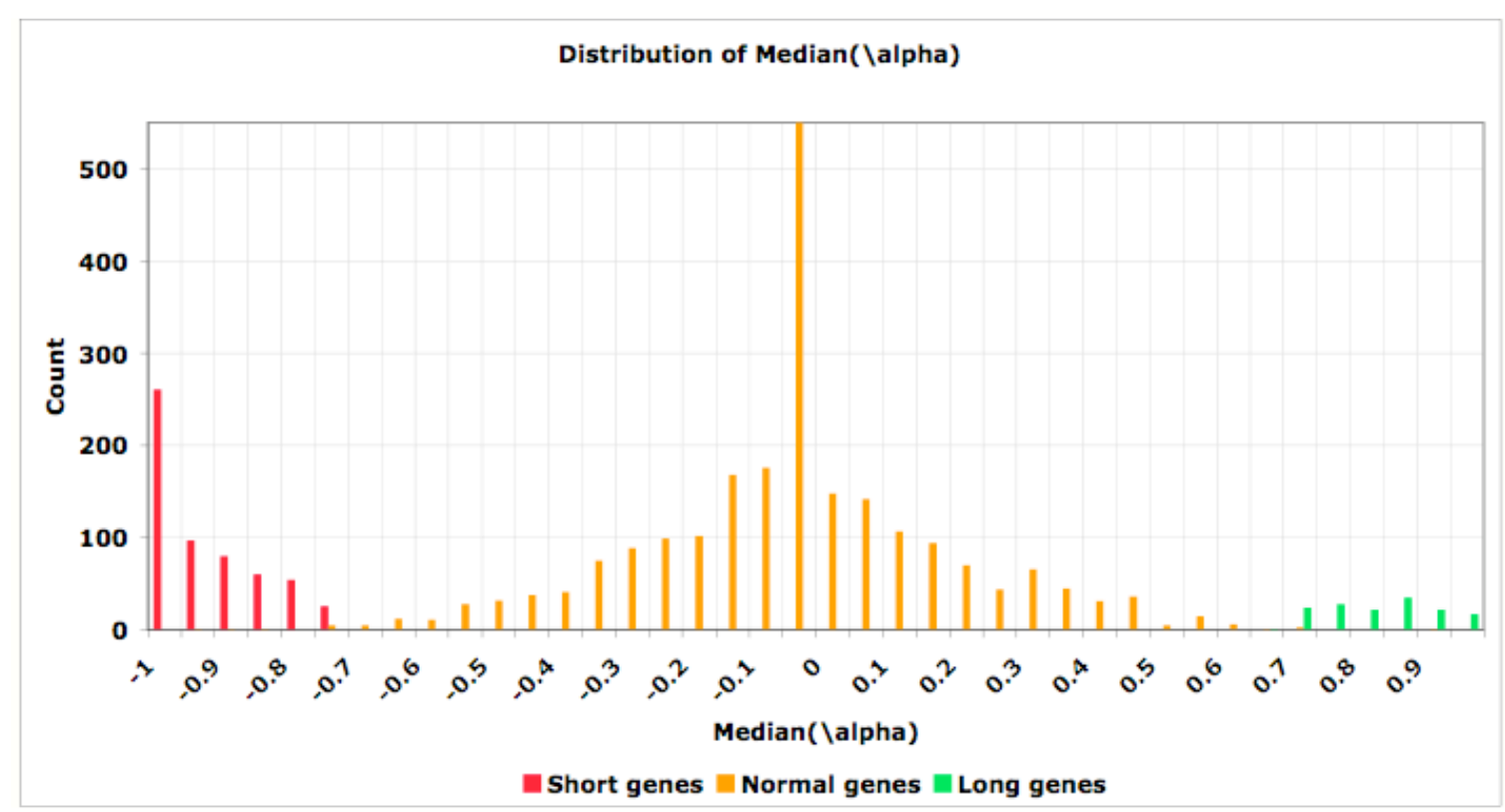

Distribution of median alignment scores $(\alpha)$ in short, matching, and long genes. Data plotted is from gene calls made by Prodigal for five genomes with $68.3 \%, 56.4 \%, 58.65 \%, 42.83 \%$, and $65.1 \%$ GC content, respectively. 
Supplementary Table 1: Alignment scores $(\alpha)$ for short, matching, and long genes

\begin{tabular}{|c|c|c|c|c|}
\hline & & $\mathbf{A}=\operatorname{Mean}(\alpha)$ & $B=\operatorname{Median}(\alpha)$ & A-B \\
\hline \multirow[t]{2}{*}{ Short } & Mean & -0.8679038 & -0.9094527 & 0.0457019 \\
\hline & STDV & 0.11813249 & 0.08122121 & 0.06656605 \\
\hline \multirow[t]{2}{*}{ Long } & Mean & 0.76133435 & 0.84391287 & 0.08340594 \\
\hline & STDV & 0.11125017 & 0.07862425 & 0.07197461 \\
\hline \multirow[t]{2}{*}{ Matching } & Mean & -0.0372008 & -0.0171879 & 0.06741398 \\
\hline & STDV & 0.18803534 & 0.20608396 & 0.06731796 \\
\hline
\end{tabular}

The mean and median values of $\alpha$ were calculated based on genes from five genomes that had been manually curated and identified as long, short, or matching genes. 
Supplementary Data 1: Statistics of all public contigs processed by GenePRIMP

\begin{tabular}{|c|c|c|c|c|c|c|c|c|c|c|c|c|c|c|c|c|c|}
\hline Contigs from ORNL & $\begin{array}{l}\text { Genome } \\
\text { GC\% }\end{array}$ & CDSs & $\begin{array}{l}\text { Shor } \\
\text { t } \\
\text { gene } \\
\text { s }\end{array}$ & \begin{tabular}{|l|} 
Extend \\
ed \\
short \\
genes
\end{tabular} & $\begin{array}{l}\text { Long } \\
\text { genes }\end{array}$ & $\begin{array}{l}\text { Trimme } \\
\text { d long } \\
\text { genes }\end{array}$ & \begin{tabular}{|l|} 
Uniqu \\
e \\
genes
\end{tabular} & \begin{tabular}{|l|} 
Dubi \\
ous \\
genes
\end{tabular} & \begin{tabular}{|l|} 
Bro \\
ken \\
gene \\
S
\end{tabular} & $\begin{array}{l}\text { Interu } \\
\text { pted } \\
\text { genes }\end{array}$ & \begin{tabular}{|l|} 
Misse \\
d \\
genes
\end{tabular} & \begin{tabular}{|l|} 
Adde \\
d \\
genes
\end{tabular} & $\begin{array}{l}\text { Delet } \\
\text { ed } \\
\text { genes }\end{array}$ & \begin{tabular}{|l|} 
Pseud \\
o \\
genes
\end{tabular} & \begin{tabular}{|l|}
$\%$ \\
correc \\
tions \\
\end{tabular} & \begin{tabular}{|l|} 
Total \\
number \\
of \\
anomali \\
es
\end{tabular} & Date \\
\hline $\begin{array}{l}\text { Arthrobacter chlorophenolicus } \\
\text { A6, Contig } 2893\end{array}$ & 65.9 & 151 & 12 & 4 & 2 & 3 & 2 & 0 & 0 & 0 & 17 & 8 & 4 & 4 & 7.538 & 36 & $10 / 22 / 08$ \\
\hline $\begin{array}{l}\text { Methylobacterium nodulans } \\
\text { ORS 2060, Contig } 403\end{array}$ & 68.4 & 47 & 2 & 1 & 1 & 1 & 0 & 0 & 0 & 0 & 3 & 2 & 0 & 1 & 15.71 & 6 & $9 / 16 / 08$ \\
\hline $\begin{array}{l}\text { Methylobacterium } \\
\text { chloromethanicum CM4, Contig } \\
430\end{array}$ & 0 & 5355 & 213 & 0 & 176 & 0 & 104 & 2 & 24 & 19 & 649 & 0 & 0 & 0 & 0 & 1676 & $8 / 1 / 08$ \\
\hline $\begin{array}{l}\text { Methylobacterium } \\
\text { chloromethanicum CM4, Contig } \\
429\end{array}$ & 0 & 346 & 0 & 0 & 0 & 0 & 0 & 0 & 0 & 0 & 0 & 0 & 0 & 0 & 0 & 0 & $8 / 1 / 08$ \\
\hline $\begin{array}{l}\text { Methylobacterium } \\
\text { chloromethanicum CM4, Contig } \\
428\end{array}$ & 0 & 36 & 0 & 0 & 0 & 0 & 0 & 0 & 0 & 0 & 0 & 0 & 0 & 0 & 0 & 0 & $8 / 1 / 08$ \\
\hline $\begin{array}{l}\text { Methylobacterium nodulans } \\
\text { ORS 2060, Contig } 454\end{array}$ & 68.4 & 7643 & 326 & 222 & 162 & 110 & 24 & 2 & 56 & 0 & 329 & 172 & 116 & 301 & 15.71 & 899 & $8 / 13 / 08$ \\
\hline $\begin{array}{l}\text { Methylobacterium nodulans } \\
\text { ORS 2060, Contig } 400\end{array}$ & 68.4 & 8 & 0 & 1 & 0 & 0 & 0 & 0 & 0 & 0 & 1 & 2 & 2 & 1 & 15.71 & 1 & $8 / 13 / 08$ \\
\hline $\begin{array}{l}\text { Methylobacterium nodulans } \\
\text { ORS 2060, Contig } 401\end{array}$ & 68.4 & 13 & 0 & 0 & 0 & 0 & 0 & 0 & 0 & 0 & 0 & 1 & 1 & 0 & 15.71 & 0 & $8 / 13 / 08$ \\
\hline $\begin{array}{l}\text { Methylobacterium nodulans } \\
\text { ORS 2060, Contig } 402\end{array}$ & 68.4 & 21 & 1 & 0 & 0 & 0 & 0 & 0 & 2 & 0 & 1 & 2 & 0 & 2 & 15.71 & 4 & $8 / 13 / 08$ \\
\hline $\begin{array}{l}\text { Methylobacterium nodulans } \\
\text { ORS 2060, Contig } 404\end{array}$ & 68.4 & 59 & 7 & 6 & 0 & 1 & 0 & 0 & 0 & 0 & 11 & 3 & 2 & 7 & 15.71 & 18 & $8 / 13 / 08$ \\
\hline $\begin{array}{l}\text { Methylobacterium nodulans } \\
\text { ORS 2060, Contig } 406\end{array}$ & 68.4 & 456 & 52 & 34 & 21 & 16 & 3 & 0 & 8 & 6 & 107 & 45 & 19 & 72 & 15.71 & 217 & $8 / 13 / 08$ \\
\hline $\begin{array}{l}\text { Methylobacterium nodulans } \\
\text { ORS 2060, Contig } 407\end{array}$ & 68.4 & 487 & 54 & 44 & 24 & 13 & 1 & 1 & 24 & 13 & 119 & 45 & 28 & 101 & 15.71 & 248 & $8 / 13 / 08$ \\
\hline $\begin{array}{l}\text { Halorubrum lacusprofundi } \\
\text { ATCC 49239, Contig } 286\end{array}$ & 66.5 & 2749 & 75 & 31 & 127 & 54 & 34 & 0 & 9 & 6 & 29 & 8 & 9 & 33 & 8.55 & 274 & $8 / 15 / 08$ \\
\hline
\end{tabular}


Halorubrum lacusprofundi ATCC 49239, Contig 285

Halorubrum lacusprofundi

ATCC 49239, Contig 284

Cyanothece sp. PCC 7424,

Contig 955

Cyanothece sp. PCC 7424

Contig 954

Cyanothece sp. PCC 7424,

Contig 953

Cyanothece sp. PCC 7424,

Contig 952

Cyanothece sp. PCC 7424,

Contig 951

Cyanothece sp. PCC 7424

Contig 950

Cyanothece sp. PCC 7424,

Contig 949

Thauera sp. MZ1T, Contig 150

Thauera sp. MZ1T, Contig 150

6724, Contig 33

Desulfitobacterium hafniense

DCB-2

Cyanothece sp. PCC 8801,

Contig 848

Cyanothece sp. PCC 8801,

Contig 847

Cyanothece sp. PCC 8801,

Contig 846

Cyanothece sp. PCC 8801,

Contig 845

Desulfitobacterium hafniense

DCB-2, Part 2

Methanosphaerula palustris E1-

$9 \mathrm{c}$

Desulfatibacillum alkenivorans

AK-01

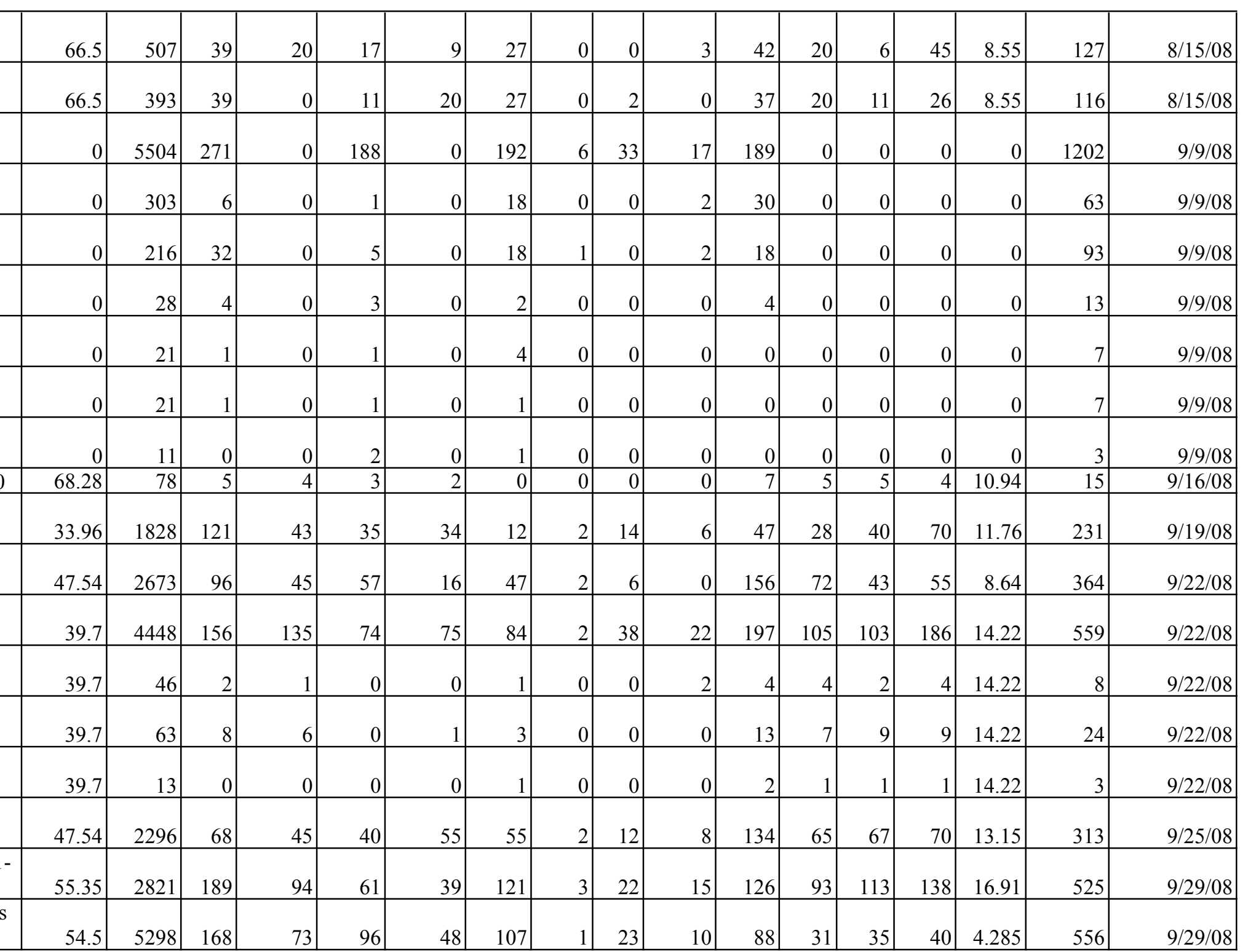




\begin{tabular}{|c|c|c|c|c|c|c|c|c|c|c|c|c|c|c|c|c|c|}
\hline Chloroflexus aggregans & 56.4 & 4009 & 121 & 79 & 51 & 62 & 105 & 6 & 47 & 10 & 91 & 59 & 218 & 110 & 13.17 & 529 & $9 / 29 / 08$ \\
\hline $\begin{array}{l}\text { Shewanella baltica OS223, } \\
\text { Contig } 72\end{array}$ & 46.3 & 4389 & 94 & 77 & 34 & 35 & 61 & 2 & 25 & 15 & 266 & 41 & 89 & 57 & 7.123 & 558 & $9 / 30 / 08$ \\
\hline $\begin{array}{l}\text { Shewanella baltica OS223, } \\
\text { Contig } 71\end{array}$ & 46.3 & 64 & 4 & 4 & 0 & 0 & 3 & 0 & 0 & 0 & 4 & 1 & 0 & 2 & 7.123 & 11 & $9 / 30 / 08$ \\
\hline $\begin{array}{l}\text { Shewanella baltica OS223, } \\
\text { Contig } 70\end{array}$ & 46.3 & 50 & 0 & 0 & 0 & 0 & 0 & 0 & 0 & 0 & 0 & 0 & 0 & 0 & 7.123 & 0 & $9 / 30 / 08$ \\
\hline $\begin{array}{l}\text { Shewanella baltica OS223, } \\
\text { Contig } 69\end{array}$ & 46.3 & 88 & 4 & 2 & 1 & 1 & 4 & 0 & 0 & 0 & 11 & 6 & 5 & 7 & 7.123 & 22 & 9/30/08 \\
\hline $\begin{array}{l}\text { Ammonifex degensii } \mathrm{KC} 4, \\
\text { Contig } 110\end{array}$ & 59.45 & 29 & 0 & 1 & 2 & 2 & 1 & 0 & 0 & 0 & 2 & 0 & 0 & 1 & 15.99 & 7 & $8 / 18 / 09$ \\
\hline $\begin{array}{l}\text { Geobacillus sp. Y412MC10, } \\
\text { Contig } 107\end{array}$ & 51.24 & 6332 & 151 & 110 & 133 & 86 & 115 & 0 & 38 & 31 & 144 & 71 & 58 & 103 & 6.76 & 693 & $8 / 21 / 09$ \\
\hline $\begin{array}{l}\text { Halothiobacillus neapolitanus } \\
\mathrm{c} 2 \text {, Contig } 14\end{array}$ & 54.71 & 2433 & 66 & 42 & 81 & 33 & 65 & 2 & 21 & 0 & 73 & 47 & 64 & 55 & 9.9 & 366 & $8 / 21 / 09$ \\
\hline $\begin{array}{l}\text { Sulfolobus solfataricus } 98 / 2 \text {, } \\
\text { Contig } 83\end{array}$ & 35.83 & 3032 & 128 & 171 & 45 & 32 & 50 & 2 & 111 & 131 & 317 & 124 & 237 & 224 & 26 & 906 & $8 / 21 / 09$ \\
\hline $\begin{array}{l}\text { Arthrobacter chlorophenolicus } \\
\text { A6, Contig } 2890\end{array}$ & 65.9 & 556 & 23 & 3 & 6 & 4 & 33 & 1 & 0 & 0 & 7 & 2 & 8 & 1 & 7.538 & 79 & $10 / 22 / 08$ \\
\hline $\begin{array}{l}\text { Arthrobacter chlorophenolicus } \\
\text { A6, Contig } 2883\end{array}$ & 65.9 & 3976 & 126 & 109 & 98 & 61 & 46 & 3 & 20 & 20 & 97 & 23 & 62 & 57 & 7.538 & 443 & $10 / 22 / 08$ \\
\hline $\begin{array}{l}\text { Cyanothece PCC 7425, Contig } \\
116\end{array}$ & 50.6 & 29 & 0 & 1 & 0 & 0 & 0 & 0 & 0 & 0 & 0 & 0 & 1 & 0 & 8.659 & 0 & $10 / 22 / 08$ \\
\hline $\begin{array}{l}\text { Cyanothece PCC 7425, Contig } \\
117\end{array}$ & 50.6 & 207 & 26 & 14 & 5 & 5 & 20 & 0 & 8 & 2 & 22 & 5 & 5 & 25 & 8.659 & 87 & $10 / 22 / 08$ \\
\hline $\begin{array}{l}\text { Cyanothece PCC 7425, Contig } \\
118\end{array}$ & 50.6 & 177 & 17 & 5 & 8 & 5 & 18 & 0 & 2 & 0 & 9 & 2 & 10 & 8 & 8.659 & 61 & $10 / 22 / 08$ \\
\hline $\begin{array}{l}\text { Cyanothece PCC 7425, Contig } \\
120\end{array}$ & 50.6 & 5119 & 178 & 63 & 113 & 82 & 155 & 3 & 46 & 16 & 137 & 56 & 99 & 93 & 8.659 & 743 & $10 / 22 / 08$ \\
\hline $\begin{array}{l}\text { Anaeromyxobacter } \\
\text { dehalogenans strain } 2 \mathrm{CP}-1 \text {, } \\
\text { Contig } 193 \\
\end{array}$ & 74.72 & 4523 & 65 & 39 & 24 & 19 & 3 & 0 & 23 & 6 & 212 & 21 & 28 & 39 & 3.228 & 394 & $10 / 23 / 08$ \\
\hline $\begin{array}{l}\text { Methanocaldococcus vulcanius } \\
\text { M7, Contig } 80\end{array}$ & 31.49 & 2 & 0 & 0 & 0 & 0 & 0 & 0 & 0 & 0 & 0 & 0 & 0 & 0 & 8.63 & 0 & $8 / 21 / 09$ \\
\hline $\begin{array}{l}\text { Desulfovibrio desulfuricans } \\
27774\end{array}$ & 58.07 & 2410 & 51 & 19 & 73 & 55 & 46 & 3 & 10 & 2 & 30 & 9 & 33 & 26 & 5.892 & 281 & $11 / 5 / 08$ \\
\hline
\end{tabular}




\begin{tabular}{|c|c|c|c|c|c|c|c|c|c|c|c|c|c|c|c|c|c|}
\hline Thioalkalivibrio sp. HL-EbGR7 & 65.1 & 3367 & 154 & 94 & 48 & 38 & 41 & 1 & 37 & 24 & 131 & 64 & 108 & 106 & 12.18 & 463 & $11 / 11 / 08$ \\
\hline Clostridium cellulolyticum H10 & 37.4 & 3546 & 101 & 62 & 44 & 44 & 96 & 2 & 22 & 14 & 124 & 75 & 128 & 98 & 11.48 & 513 & $11 / 17 / 08$ \\
\hline Diaphorobacter sp. TPSY & 66.83 & 3528 & 127 & 118 & 40 & 49 & 14 & 1 & 6 & 10 & 252 & 61 & 42 & 74 & 9.751 & 481 & $11 / 20 / 08$ \\
\hline $\begin{array}{l}\text { Geobacillus sp. WCH70, Contig } \\
196\end{array}$ & 43.83 & 3468 & 152 & 119 & 42 & 78 & 57 & 1 & 43 & 47 & 328 & 181 & 203 & 308 & 25.74 & 777 & $11 / 20 / 08$ \\
\hline $\begin{array}{l}\text { Geobacillus sp. WCH70, Contig } \\
193\end{array}$ & 43.83 & 33 & 2 & 2 & 0 & 1 & 0 & 0 & 0 & 0 & 4 & 3 & 1 & 3 & 25.74 & 8 & $11 / 20 / 08$ \\
\hline $\begin{array}{l}\text { Geobacillus sp. WCH70, Contig } \\
192\end{array}$ & 43.83 & 11 & 1 & 1 & 0 & 0 & 1 & 0 & 0 & 0 & 0 & 1 & 3 & 0 & 25.74 & 4 & $11 / 20 / 08$ \\
\hline $\begin{array}{l}\text { Anaerocellum thermophilum, } \\
\text { Contig } 268\end{array}$ & 35.17 & 2829 & 90 & 47 & 31 & 23 & 52 & 4 & 42 & 23 & 190 & 57 & 110 & 98 & 11.82 & 520 & $12 / 1 / 08$ \\
\hline $\begin{array}{l}\text { Anaerocellum thermophilum, } \\
\text { Contig } 263\end{array}$ & 35.17 & 8 & 0 & 1 & 1 & 0 & 1 & 0 & 0 & 0 & 0 & 0 & 0 & 0 & 11.82 & 2 & $12 / 1 / 08$ \\
\hline $\begin{array}{l}\text { Anaerocellum thermophilum, } \\
\text { Contig } 259\end{array}$ & 35.17 & 4 & 1 & 0 & 0 & 0 & 0 & 0 & 0 & 0 & 0 & 0 & 0 & 0 & 11.82 & 1 & $12 / 1 / 08$ \\
\hline Geobacter sp. FRC-32 & 53.47 & 3837 & 85 & 41 & 52 & 44 & 56 & 1 & 32 & 2 & 151 & 34 & 31 & 41 & 4.98 & 455 & $12 / 8 / 08$ \\
\hline $\begin{array}{l}\text { Ralstonia pickettii 12D, Contig } \\
80\end{array}$ & 63.56 & 3467 & 94 & 64 & 54 & 48 & 42 & 2 & 21 & 11 & 387 & 24 & 30 & 49 & 6.59 & 652 & $12 / 9 / 08$ \\
\hline $\begin{array}{l}\text { Ralstonia pickettii 12D, Contig } \\
79\end{array}$ & 63.56 & 1204 & 42 & 23 & 22 & 15 & 16 & 1 & 6 & 0 & 77 & 12 & 11 & 24 & 6.59 & 185 & $12 / 9 / 08$ \\
\hline $\begin{array}{l}\text { Ralstonia pickettii 12D, Contig } \\
78\end{array}$ & 63.56 & 431 & 28 & 6 & 3 & 6 & 32 & 0 & 2 & 0 & 20 & 2 & 1 & 5 & 6.59 & 93 & $12 / 9 / 08$ \\
\hline $\begin{array}{l}\text { Ralstonia pickettii 12D, Contig } \\
77\end{array}$ & 63.56 & 289 & 15 & 9 & 6 & 4 & 14 & 1 & 2 & 4 & 36 & 5 & 7 & 11 & 6.59 & 82 & $12 / 9 / 08$ \\
\hline $\begin{array}{l}\text { Ralstonia pickettii 12D, Contig } \\
76\end{array}$ & 63.56 & 69 & 7 & 2 & 0 & 0 & 4 & 0 & 0 & 0 & 7 & 0 & 1 & 1 & 6.59 & 18 & $12 / 9 / 08$ \\
\hline $\begin{array}{l}\text { Sulfolobus islandicus U.3.28, } \\
\text { Contig } 145\end{array}$ & 34.64 & 3175 & 113 & 80 & 41 & 56 & 68 & 1 & 93 & 43 & 266 & 84 & 167 & 170 & 17.54 & 766 & $1 / 13 / 09$ \\
\hline HRB1 sp., Contig 19 & 49.03 & 3193 & 59 & 33 & 39 & 27 & 31 & 0 & 4 & 8 & 96 & 31 & 60 & 41 & 6.01 & 329 & $1 / 26 / 09$ \\
\hline $\begin{array}{l}\text { Rhizobium leguminosarum bv. } \\
\text { trifolii WSM1325, Contig } 1172\end{array}$ & 61.09 & 316 & 7 & 6 & 2 & 4 & 7 & 0 & 4 & 2 & 20 & 11 & 6 & 12 & 10.78 & 89 & $2 / 6 / 09$ \\
\hline $\begin{array}{l}\text { Rhizobium leguminosarum bv. } \\
\text { trifolii WSM1325, Contig } 1165\end{array}$ & 61.09 & 529 & 39 & 28 & 10 & 10 & 33 & 0 & 8 & 6 & 73 & 54 & 21 & 64 & 10.78 & 180 & $2 / 6 / 09$ \\
\hline
\end{tabular}




\begin{tabular}{|c|c|c|c|c|c|c|c|c|c|c|c|c|c|c|c|c|c|}
\hline $\begin{array}{l}\text { Rhizobium leguminosarum bv. } \\
\text { trifolii WSM1325, Contig } 1171\end{array}$ & 61.09 & 312 & 8 & 5 & 4 & 2 & 6 & 0 & 2 & 2 & 27 & 9 & 4 & 9 & 10.78 & 67 & $2 / 6 / 09$ \\
\hline $\begin{array}{l}\text { Rhizobium leguminosarum bv. } \\
\text { trifolii WSM1325, Contig } 1170\end{array}$ & 61.09 & 691 & 35 & 25 & 9 & 9 & 17 & 0 & 6 & 7 & 73 & 29 & 14 & 37 & 10.78 & 262 & $2 / 6 / 09$ \\
\hline $\begin{array}{l}\text { Rhizobium leguminosarum bv. } \\
\text { trifolii WSM1325, Contig } 1169\end{array}$ & 61.09 & 786 & 25 & 25 & 15 & 13 & 7 & 1 & 12 & 12 & 70 & 24 & 15 & 31 & 10.78 & 229 & $2 / 6 / 09$ \\
\hline $\begin{array}{l}\text { Rhizobium leguminosarum bv. } \\
\text { trifolii WSM1325, Contig } 1168\end{array}$ & 61.09 & 4642 & 77 & 73 & 84 & 59 & 78 & 0 & 30 & 24 & 347 & 66 & 45 & 74 & 10.78 & 730 & $2 / 6 / 09$ \\
\hline $\begin{array}{l}\text { Variovorax paradoxus S110, } \\
\text { Contig } 49\end{array}$ & 67.63 & 1052 & 44 & 25 & 23 & 20 & 16 & 1 & 6 & 0 & 47 & 37 & 9 & 42 & 7.19 & 146 & $2 / 19 / 09$ \\
\hline $\begin{array}{l}\text { Exiguobacterium sp. AT1b, } \\
\text { Contig } 100\end{array}$ & 48.46 & 3078 & 66 & 22 & 28 & 27 & 46 & 4 & 7 & 10 & 27 & 11 & 46 & 24 & 4.22 & 268 & 2/19/09 \\
\hline $\begin{array}{l}\text { Variovorax paradoxus S110, } \\
\text { Contig } 54\end{array}$ & 67.63 & 5264 & 167 & 105 & 66 & 67 & 47 & 3 & 25 & 6 & 124 & 61 & 22 & 66 & 7.19 & 487 & $2 / 19 / 09$ \\
\hline Thauera sp. MZ1T, Contig 151 & 68.4 & 3992 & 116 & 104 & 97 & 73 & 28 & 1 & 45 & 40 & 156 & 58 & 71 & 109 & 10.78 & 500 & $2 / 28 / 09$ \\
\hline $\begin{array}{l}\text { Thermotogales bacterium TBF } \\
\text { 19.5.1, Contig } 147\end{array}$ & 41.55 & 2191 & 57 & 35 & 32 & 35 & 24 & 0 & 38 & 12 & 45 & 25 & 42 & 51 & 8.35 & 286 & $3 / 10 / 09$ \\
\hline $\begin{array}{l}\text { Pectobacterium carotovorum } \\
\text { subsp. wasabiae, Contig } 316\end{array}$ & 50.48 & 4526 & 113 & 80 & 97 & 64 & 76 & 1 & 29 & 19 & 353 & 157 & 62 & 178 & 11.95 & 733 & $7 / 7 / 09$ \\
\hline $\begin{array}{l}\text { Dickeya dadantii Ech1591, } \\
\text { Contig } 74\end{array}$ & 54.52 & 4229 & 108 & 80 & 83 & 63 & 67 & 0 & 21 & 17 & 270 & 92 & 43 & 104 & 9.03 & 607 & $3 / 11 / 09$ \\
\hline $\begin{array}{l}\text { Fibrobacter succinogenes S85 } \\
\text { ATCC } 19169 \text {, Contig } 123\end{array}$ & 48.05 & 3133 & 120 & 40 & 79 & 24 & 60 & 1 & 13 & 18 & 31 & 26 & 30 & 34 & 4.9 & 358 & $8 / 14 / 09$ \\
\hline $\begin{array}{l}\text { Ammonifex degensii KC4, } \\
\text { Contig } 140\end{array}$ & 59.45 & 2191 & 117 & 83 & 27 & 34 & 29 & 5 & 50 & 58 & 77 & 51 & 82 & 101 & 15.99 & 494 & $8 / 18 / 09$ \\
\hline $\begin{array}{l}\text { Pectobacterium carotovorum } \\
\text { ssp. carotovorum PC1, Contig } \\
58\end{array}$ & 51.93 & 4292 & 70 & 60 & 84 & 49 & 59 & 1 & 22 & 12 & 218 & 45 & 37 & 49 & 5.59 & 506 & $3 / 31 / 09$ \\
\hline $\begin{array}{l}\text { Paenibacillus sp. JDR-2, Contig } \\
301\end{array}$ & 50.28 & 6307 & 163 & 70 & 91 & 63 & 83 & 0 & 47 & 43 & 103 & 44 & 60 & 70 & 4.87 & 586 & $3 / 31 / 09$ \\
\hline $\begin{array}{l}\text { Desulfovibrio salexigens DSM } \\
2638 \text {, Contig } 92\end{array}$ & 47.09 & 3857 & 85 & 55 & 47 & 29 & 35 & 1 & 41 & 27 & 37 & 17 & 39 & 25 & 4.28 & 326 & 4/9/09 \\
\hline Geobacter sp. M21, Contig 449 & 60.47 & 4109 & 84 & 59 & 46 & 41 & 28 & 0 & 39 & 18 & 196 & 72 & 27 & 72 & 6.6 & 442 & $4 / 14 / 09$ \\
\hline
\end{tabular}




\begin{tabular}{|c|c|c|c|c|c|c|c|c|c|c|c|c|c|c|c|c|c|}
\hline $\begin{array}{l}\text { Escherichia coli BL21(DE3), } \\
\text { Contig } 2859\end{array}$ & 50.84 & 4308 & 125 & 135 & 6 & 13 & 4 & 1 & 58 & 64 & 1026 & 137 & 101 & 99 & 11.26 & 1343 & $4 / 21 / 09$ \\
\hline $\begin{array}{l}\text { Methanocaldococcus fervens } \\
\text { AG86, Contig } 452\end{array}$ & 32.21 & 35 & 1 & 1 & 1 & 1 & 1 & 0 & 0 & 0 & 0 & 0 & 0 & 0 & 11.3 & 4 & 7/17/09 \\
\hline $\begin{array}{l}\text { Methanocaldococcus fervens } \\
\text { AG86, Contig } 453\end{array}$ & 32.21 & 1622 & 55 & 46 & 32 & 28 & 15 & 0 & 40 & 22 & 58 & 21 & 51 & 39 & 11.3 & 261 & 7/17/09 \\
\hline $\begin{array}{l}\text { Methanococcus voltae A3, } \\
\text { Contig } 1958\end{array}$ & 28.59 & 1740 & 37 & 29 & 135 & 47 & 21 & 0 & 15 & 12 & 22 & 5 & 20 & 3 & 5.98 & 252 & $7 / 23 / 09$ \\
\hline $\begin{array}{l}\text { Bacillus selenitireducens MLS- } \\
10, \text { ATCC } 700615 \text {, Contig } 105\end{array}$ & 48.67 & 3377 & 63 & 78 & 48 & 36 & 54 & 1 & 84 & 80 & 138 & 37 & 88 & 74 & 9.27 & 473 & $7 / 28 / 09$ \\
\hline $\begin{array}{l}\text { Zymomonas mobilis pomaceae } \\
\text { lectotype ATCC 29192, Contig } \\
34\end{array}$ & 44.09 & 42 & 1 & 2 & 0 & 0 & 1 & 0 & 4 & 4 & 6 & 3 & 8 & 3 & 6.25 & 16 & $8 / 4 / 09$ \\
\hline $\begin{array}{l}\text { Zymomonas mobilis pomaceae } \\
\text { lectotype ATCC 29192, Contig } \\
35\end{array}$ & 44.09 & 1701 & 37 & 27 & 31 & 15 & 10 & 0 & 12 & 14 & 57 & 18 & 18 & 15 & 6.25 & 174 & $8 / 4 / 09$ \\
\hline $\begin{array}{l}\text { Lutiella nitroferrum 2002, } \\
\text { Contig } 81\end{array}$ & 64.57 & 3905 & 116 & 54 & 53 & 44 & 45 & 4 & 0 & 7 & 0 & 13 & 25 & 25 & 4.12 & 265 & $8 / 6 / 09$ \\
\hline $\begin{array}{l}\text { Methanocaldococcus vulcanius } \\
\text { M7, Contig } 84\end{array}$ & 31.49 & 13 & 0 & 1 & 0 & 0 & 2 & 0 & 0 & 0 & 1 & 1 & 0 & 1 & 8.63 & 4 & $8 / 21 / 09$ \\
\hline $\begin{array}{l}\text { Methanocaldococcus vulcanius } \\
\text { M7, Contig } 94\end{array}$ & 31.49 & 1769 & 47 & 31 & 44 & 31 & 36 & 1 & 16 & 8 & 57 & 32 & 35 & 22 & 8.63 & 260 & $8 / 24 / 09$ \\
\hline $\begin{array}{l}\text { Geobacillus sp. Y412MC61, } \\
\text { Contig } 130\end{array}$ & 52.42 & 40 & 2 & 0 & 1 & 0 & 1 & 0 & 0 & 0 & 7 & 1 & 1 & 1 & 14.57 & 11 & $8 / 27 / 09$ \\
\hline $\begin{array}{l}\text { Geobacillus sp. Y412MC61, } \\
\text { Contig } 166\end{array}$ & 52.42 & 3577 & 90 & 82 & 65 & 59 & 47 & 0 & 64 & 55 & 363 & 107 & 115 & 163 & 14.57 & 789 & $8 / 28 / 09$ \\
\hline $\begin{array}{l}\text { Victivallis vadensis ATCC BAA- } \\
548 \text {, permanent draft }\end{array}$ & 59 & 4129 & 141 & 53 & 88 & 26 & 54 & 3 & 22 & 18 & 53 & 36 & 32 & 59 & 4.99 & 445 & $9 / 2 / 09$ \\
\hline $\begin{array}{l}\text { Clostridium thermocellum DSM } \\
4150, \text { Permanent draft }\end{array}$ & 39 & 3345 & 95 & 101 & 45 & 30 & 72 & 1 & 100 & 20 & 241 & 116 & 191 & 182 & 18.55 & 665 & $9 / 2 / 09$ \\
\hline $\begin{array}{l}\text { Nostoc azollae 0708, Contig } \\
953\end{array}$ & 38.45 & 13 & 1 & 2 & 0 & 0 & 3 & 0 & 0 & 0 & 5 & 1 & 0 & 3 & 82 & 9 & $9 / 20 / 09$ \\
\hline $\begin{array}{l}\text { Nostoc azollae 0708, Contig } \\
1927\end{array}$ & 38.45 & 159 & 21 & 41 & 0 & 1 & 16 & 1 & 60 & 2 & 74 & 21 & 66 & 63 & 82 & 172 & $9 / 20 / 09$ \\
\hline $\begin{array}{l}\text { Nostoc azollae 0708, Contig } \\
2627\end{array}$ & 38.45 & 6726 & 608 & 987 & 129 & 114 & 468 & 9 & 1877 & 388 & 1951 & 622 & 2118 & 1620 & 82 & 5252 & $9 / 23 / 09$ \\
\hline
\end{tabular}




\begin{tabular}{|c|c|c|c|c|c|c|c|c|c|c|c|c|c|c|c|c|c|}
\hline $\begin{array}{l}\text { Desulfonatronospira } \\
\text { thiodismutans ASO3-1 }\end{array}$ & 0 & 3794 & 114 & 0 & 59 & 0 & 190 & 0 & 47 & 30 & 266 & 0 & 0 & 0 & 0 & 803 & $1 / 27 / 10$ \\
\hline $\begin{array}{l}\text { Thermotoga naphthophila RKU- } \\
10 \text {, Contig } 4\end{array}$ & 0 & 1827 & 41 & 0 & 17 & 0 & 5 & 0 & 44 & 36 & 96 & 0 & 0 & 0 & 0 & 346 & 9/30/09 \\
\hline $\begin{array}{l}\text { Thermoanaerobacter italicus } \\
\text { Ab9 DSM 9252, Contig } 360\end{array}$ & 34.14 & 2386 & 44 & 56 & 18 & 27 & 31 & 0 & 63 & 20 & 210 & 96 & 70 & 137 & 16.18 & 429 & $11 / 10 / 09$ \\
\hline $\begin{array}{l}\text { Dickeya dadantii Ech586, } \\
\text { Contig } 42\end{array}$ & 53.64 & 4192 & 56 & 68 & 62 & 31 & 77 & 1 & 18 & 4 & 279 & 72 & 44 & 72 & 6.85 & 543 & $10 / 22 / 09$ \\
\hline $\begin{array}{l}\text { Zymomonas mobilis subsp. } \\
\text { mobilis ATCC 10988, Contig } 11\end{array}$ & 46.22 & 2 & 0 & 0 & 0 & 0 & 0 & 0 & 0 & 0 & 0 & 0 & 0 & 0 & 15.64 & 0 & $10 / 26 / 09$ \\
\hline $\begin{array}{l}\text { Zymomonas mobilis subsp. } \\
\text { mobilis ATCC 10988, Contig } 12\end{array}$ & 46.22 & 3 & 0 & 0 & 0 & 0 & 0 & 0 & 0 & 0 & 0 & 0 & 0 & 0 & 15.64 & 0 & $10 / 26 / 09$ \\
\hline $\begin{array}{l}\text { Zymomonas mobilis subsp. } \\
\text { mobilis ATCC 10988, Contig } 13\end{array}$ & 46.22 & 31 & 2 & 1 & 0 & 2 & 0 & 0 & 2 & 0 & 12 & 9 & 2 & 10 & 15.64 & 16 & $10 / 26 / 09$ \\
\hline $\begin{array}{l}\text { Zymomonas mobilis subsp. } \\
\text { mobilis ATCC 10988, Contig } 14\end{array}$ & 46.22 & 32 & 2 & 1 & 0 & 2 & 2 & 0 & 2 & 0 & 6 & 8 & 8 & 8 & 15.64 & 12 & $10 / 26 / 09$ \\
\hline $\begin{array}{l}\text { Zymomonas mobilis subsp. } \\
\text { mobilis ATCC 10988, Contig } 15\end{array}$ & 46.22 & 24 & 0 & 0 & 1 & 0 & 1 & 0 & 0 & 0 & 7 & 3 & 0 & 3 & 15.64 & 9 & $10 / 26 / 09$ \\
\hline $\begin{array}{l}\text { Zymomonas mobilis subsp. } \\
\text { mobilis ATCC 10988, Contig } 16\end{array}$ & 46.22 & 28 & 1 & 1 & 0 & 0 & 0 & 0 & 0 & 0 & 10 & 6 & 2 & 5 & 15.64 & 11 & $10 / 26 / 09$ \\
\hline $\begin{array}{l}\text { Allochromatium vinosum DSM } \\
180, \text { Contig } 249\end{array}$ & 64.37 & 44 & 0 & 0 & 1 & 2 & 2 & 0 & 0 & 0 & 6 & 5 & 0 & 1 & 9.05 & 11 & $10 / 27 / 09$ \\
\hline $\begin{array}{l}\text { Dehalococcoides sp. VS, Contig } \\
05\end{array}$ & 0 & 1459 & 25 & 0 & 17 & 0 & 19 & 0 & 2 & 0 & 86 & 0 & 0 & 0 & 0 & 175 & $10 / 27 / 09$ \\
\hline $\begin{array}{l}\text { Allochromatium vinosum DSM } \\
180 \text {, Contig } 250\end{array}$ & 64.37 & 126 & 6 & 5 & 4 & 0 & 9 & 0 & 2 & 0 & 14 & 7 & 4 & 8 & 9.05 & 38 & $10 / 27 / 09$ \\
\hline $\begin{array}{l}\text { Zymomonas mobilis subsp. } \\
\text { mobilis ATCC 10988, Contig } 17\end{array}$ & 46.22 & 1747 & 33 & 43 & 29 & 26 & 12 & 0 & 11 & 6 & 289 & 54 & 58 & 40 & 15.64 & 408 & $10 / 27 / 09$ \\
\hline $\begin{array}{l}\text { Allochromatium vinosum DSM } \\
180 \text {, Contig } 251\end{array}$ & 64.37 & 3091 & 66 & 59 & 58 & 41 & 37 & 1 & 13 & 4 & 116 & 64 & 27 & 72 & 9.05 & 334 & $10 / 27 / 09$ \\
\hline
\end{tabular}




\begin{tabular}{|c|c|c|c|c|c|c|c|c|c|c|c|c|c|c|c|c|c|}
\hline $\begin{array}{l}\text { Natrialba magadii ATCC 43099, } \\
\text { Contig } 64\end{array}$ & 61.42 & 3617 & 38 & 32 & 143 & 51 & 223 & 0 & 16 & 8 & 154 & 45 & 52 & 50 & 8.1 & 613 & $1 / 6 / 10$ \\
\hline $\begin{array}{l}\text { Natrialba magadii ATCC 43099, } \\
\text { Contig } 63\end{array}$ & 61.42 & 352 & 9 & 7 & 14 & 9 & 21 & 0 & 1 & 2 & 16 & 6 & 4 & 13 & 8.1 & 70 & $1 / 5 / 10$ \\
\hline $\begin{array}{l}\text { Natrialba magadii ATCC 43099, } \\
\text { Contig } 62\end{array}$ & 61.42 & 239 & 10 & 18 & 4 & 3 & 15 & 0 & 2 & 2 & 28 & 18 & 9 & 29 & 8.1 & 60 & $1 / 5 / 10$ \\
\hline $\begin{array}{l}\text { Methylotenera sp. 301, Contig } \\
1822\end{array}$ & 42.64 & 2795 & 47 & 51 & 48 & 36 & 43 & 0 & 11 & 4 & 50 & 20 & 14 & 35 & 5.58 & 226 & $10 / 28 / 09$ \\
\hline $\begin{array}{l}\text { Ferroglobus placidus DSM } \\
10642 \text {, Contig } 489\end{array}$ & 44.14 & 2589 & 66 & 55 & 21 & 17 & 95 & 0 & 36 & 5 & 71 & 51 & 68 & 87 & 10.74 & 415 & $10 / 28 / 09$ \\
\hline $\begin{array}{l}\text { Natrialba magadii ATCC 43099, } \\
\text { Contig } 61\end{array}$ & 61.42 & 94 & 1 & 0 & 2 & 1 & 3 & 0 & 0 & 0 & 2 & 0 & 0 & 0 & 8.1 & 10 & $1 / 5 / 10$ \\
\hline $\begin{array}{l}\text { Starkeya novella DSMZ, Contig } \\
92\end{array}$ & 67.88 & 4480 & 96 & 88 & 69 & 47 & 89 & 0 & 26 & 2 & 240 & 55 & 24 & 78 & 5.89 & 565 & $11 / 5 / 09$ \\
\hline $\begin{array}{l}\text { Sideroxydans lithotrophicus ES- } \\
1, \text { Contig } 246\end{array}$ & 57.54 & 2972 & 76 & 66 & 28 & 21 & 0 & 0 & 14 & 8 & 82 & 39 & 14 & 16 & 5.25 & 237 & $11 / 24 / 09$ \\
\hline $\begin{array}{l}\text { Thioalkalivibrio sp. K90mix, } \\
\text { Contig } 474\end{array}$ & 65.87 & 283 & 5 & 2 & 4 & 4 & 26 & 0 & 2 & 0 & 19 & 4 & 2 & 5 & 5.23 & 63 & $12 / 21 / 09$ \\
\hline $\begin{array}{l}\text { Thioalkalivibrio sp. K90mix, } \\
\text { Contig } 352\end{array}$ & 65.87 & 2602 & 36 & 39 & 40 & 29 & 26 & 0 & 14 & 19 & 75 & 18 & 20 & 28 & 5.23 & 237 & $12 / 21 / 09$ \\
\hline $\begin{array}{l}\text { Klebsiella variicola At-22, } \\
\text { Contig } 38\end{array}$ & 57.58 & 5038 & 62 & 61 & 41 & 42 & 20 & 0 & 5 & 0 & 720 & 73 & 10 & 41 & 4.5 & 905 & $12 / 23 / 09$ \\
\hline $\begin{array}{l}\text { Methanocaldococcus sp. FS406- } \\
22 \text {, Contig } 94\end{array}$ & 32.04 & 13 & 2 & 1 & 0 & 0 & 0 & 0 & 0 & 0 & 1 & 2 & 0 & 0 & 9.64 & 4 & $1 / 14 / 10$ \\
\hline $\begin{array}{l}\text { Methanocaldococcus sp. FS406- } \\
22 \text {, Contig } 92\end{array}$ & 32.04 & 1854 & 30 & 34 & 25 & 24 & 25 & 0 & 33 & 14 & 51 & 40 & 47 & 32 & 9.64 & 226 & $1 / 14 / 10$ \\
\hline $\begin{array}{l}\text { Zymomonas mobilis pomaceae } \\
\text { lectotype ATCC 29192, Contig } \\
56\end{array}$ & 43 & 42 & 2 & 1 & 0 & 1 & 3 & 0 & 4 & 0 & 5 & 5 & 10 & 4 & 56.98 & 18 & $1 / 14 / 10$ \\
\hline $\begin{array}{l}\text { Zymomonas mobilis pomaceae } \\
\text { lectotype ATCC 29192, Contig } \\
54\end{array}$ & 43 & 44 & 2 & 4 & 0 & 0 & 6 & 0 & 5 & 0 & 15 & 6 & 9 & 9 & 56.98 & 28 & $1 / 14 / 10$ \\
\hline $\begin{array}{l}\text { Desulfurivibrio alkaliphilus } \\
\text { AHT2, Contig } 27\end{array}$ & 60.29 & 2690 & 66 & 66 & 44 & 15 & 26 & 0 & 24 & 14 & 294 & 35 & 49 & 53 & 8.1 & 502 & $1 / 14 / 10$ \\
\hline $\begin{array}{l}\text { Dehalococcoides sp. GT, Contig } \\
14\end{array}$ & 47.31 & 1428 & 20 & 27 & 13 & 11 & 18 & 0 & 10 & 6 & 97 & 18 & 12 & 18 & 6.02 & 184 & $1 / 19 / 10$ \\
\hline
\end{tabular}




\begin{tabular}{|c|c|c|c|c|c|c|c|c|c|c|c|c|c|c|c|c|c|}
\hline $\begin{array}{l}\text { Alicyclobacillus acidocaldarius } \\
\text { LAA1 }\end{array}$ & 0 & 2981 & 104 & 0 & 37 & 0 & 106 & 0 & 51 & 20 & 272 & 0 & 0 & 0 & 0 & 652 & $1 / 23 / 10$ \\
\hline $\begin{array}{l}\text { Burkholderia sp. CCGE1002, } \\
\text { Contig } 96\end{array}$ & 0 & 487 & 35 & 0 & 4 & 0 & 27 & 0 & 37 & 13 & 100 & 0 & 0 & 0 & 0 & 214 & $2 / 2 / 10$ \\
\hline $\begin{array}{l}\text { Burkholderia sp. CCGE1002, } \\
\text { Contig } 97\end{array}$ & 0 & 1180 & 43 & 0 & 15 & 0 & 33 & 0 & 30 & 4 & 133 & 0 & 0 & 0 & 0 & 274 & $2 / 2 / 10$ \\
\hline $\begin{array}{l}\text { Burkholderia sp. CCGE1002, } \\
\text { Contig } 99\end{array}$ & 0 & 3162 & 56 & 0 & 51 & 0 & 27 & 0 & 16 & 10 & 287 & 0 & 0 & 0 & 0 & 465 & $2 / 3 / 10$ \\
\hline $\begin{array}{l}\text { Burkholderia sp. CCGE1002, } \\
\text { Contig } 98\end{array}$ & 0 & 2333 & 61 & 0 & 45 & 0 & 25 & 0 & 31 & 12 & 219 & 0 & 0 & 0 & 0 & 404 & $2 / 3 / 10$ \\
\hline $\begin{array}{l}\text { Caulobacter segnis ATCC } \\
21756 \text {, Contig } 532\end{array}$ & 0 & 4293 & 114 & 0 & 39 & 0 & 55 & 0 & 89 & 79 & 414 & 0 & 0 & 0 & 0 & 768 & $2 / 5 / 10$ \\
\hline Contigs from GEBA & $\begin{array}{l}\text { Genome } \\
\text { GC\% }\end{array}$ & CDSs & \begin{tabular}{|l|} 
Shor \\
t \\
gene \\
s \\
\end{tabular} & \begin{tabular}{|l|} 
Extend \\
ed \\
short \\
genes
\end{tabular} & $\begin{array}{l}\text { Long } \\
\text { genes }\end{array}$ & $\begin{array}{l}\text { Trimme } \\
\text { d long } \\
\text { genes }\end{array}$ & \begin{tabular}{|l|} 
Uniqu \\
e \\
genes
\end{tabular} & $\begin{array}{l}\text { Dubi } \\
\text { ous } \\
\text { genes }\end{array}$ & \begin{tabular}{|l|} 
Bro \\
ken \\
gene \\
s
\end{tabular} & \begin{tabular}{|l|} 
Interu \\
pted \\
genes
\end{tabular} & \begin{tabular}{|l|} 
Misse \\
d \\
genes
\end{tabular} & \begin{tabular}{|l|} 
Adde \\
d \\
genes
\end{tabular} & \begin{tabular}{|l|} 
Delet \\
ed \\
genes
\end{tabular} & \begin{tabular}{|l|} 
Pseud \\
o \\
genes
\end{tabular} & \begin{tabular}{|l|}
$\%$ \\
correc \\
tions \\
\\
\end{tabular} & \begin{tabular}{|l|} 
Total \\
number \\
of \\
anomali \\
es \\
\end{tabular} & Date \\
\hline $\begin{array}{l}\text { Sanguibacter keddieii DSM } \\
10542\end{array}$ & 71.9 & 3746 & 222 & 162 & 182 & 56 & 57 & 8 & 19 & 2 & 68 & 30 & 41 & 25 & 8.356 & 556 & $9 / 19 / 08$ \\
\hline $\begin{array}{l}\text { Slackia heliotrinireducens DSM } \\
20476\end{array}$ & 60.2 & 2819 & 119 & 55 & 61 & 23 & 65 & 7 & 22 & 2 & 45 & 15 & 36 & 33 & 5.747 & 320 & $9 / 23 / 08$ \\
\hline $\begin{array}{l}\text { Cryptobacterium curtum DSM } \\
15641\end{array}$ & 50.9 & 1367 & 38 & 15 & 77 & 36 & 29 & 0 & 4 & 2 & 27 & 5 & 8 & 7 & 5.194 & 175 & $9 / 25 / 08$ \\
\hline $\begin{array}{l}\text { Saccharomonospora viridis } \\
\text { P101, DSM } 43017\end{array}$ & 67.3 & 3959 & 292 & 274 & 74 & 89 & 76 & 10 & 19 & 10 & 148 & 43 & 96 & 78 & 14.65 & 676 & $9 / 29 / 08$ \\
\hline $\begin{array}{l}\text { Kytococcus sedentarius DSM } \\
20547\end{array}$ & 71.6 & 2662 & 184 & 76 & 81 & 39 & 46 & 12 & 13 & 30 & 108 & 42 & 65 & 84 & 11.5 & 478 & $10 / 2 / 08$ \\
\hline $\begin{array}{l}\text { Sulfurimonas autotrophica DSM } \\
16294 \text {, Contig } 12\end{array}$ & 35.24 & 2175 & 46 & 21 & 14 & 16 & 13 & 0 & 0 & 2 & 0 & 1 & 11 & 8 & 2.62 & 130 & $8 / 21 / 09$ \\
\hline $\begin{array}{l}\text { Desulfomicrobium baculatum } \\
\text { DSM } 4028\end{array}$ & 58.65 & 3451 & 80 & 64 & 45 & 22 & 56 & 2 & 16 & 22 & 101 & 63 & 20 & 58 & 6.58 & 365 & $12 / 10 / 08$ \\
\hline Leptotrichia buccalis DSM 1135 & 29.65 & 2335 & 59 & 45 & 42 & 30 & 40 & 1 & 62 & 48 & 68 & 58 & 84 & 91 & 13.19 & 323 & $12 / 10 / 08$ \\
\hline $\begin{array}{l}\text { Capnocytophaga ochracea DSM } \\
7271\end{array}$ & 39.59 & 2216 & 58 & 33 & 23 & 9 & 61 & 0 & 9 & 10 & 34 & 14 & 35 & 20 & 5.01 & 219 & $12 / 16 / 08$ \\
\hline
\end{tabular}




\begin{tabular}{|c|c|c|c|c|c|c|c|c|c|c|c|c|c|c|c|c|c|}
\hline $\begin{array}{l}\text { Acidimicrobium Ferrooxidans } \\
\text { DSM } 10331\end{array}$ & 68.3 & 2070 & 105 & 43 & 29 & 25 & 34 & 3 & 23 & 17 & 63 & 44 & 76 & 74 & 12.31 & 335 & $12 / 17 / 08$ \\
\hline $\begin{array}{l}\text { Actinosynnema mirum DSM } \\
43827\end{array}$ & 73.71 & 7107 & 338 & 259 & 135 & 65 & 121 & 3 & 64 & 25 & 223 & 81 & 324 & 179 & 9.43 & 943 & $12 / 17 / 08$ \\
\hline $\begin{array}{l}\text { Beutenbergia cavernae DSM } \\
12333\end{array}$ & 73.1 & 4222 & 118 & 31 & 93 & 52 & 20 & 2 & 20 & 6 & 52 & 14 & 13 & 30 & 3.31 & 335 & $12 / 17 / 08$ \\
\hline $\begin{array}{l}\text { Catenulispora acidiphila DSM } \\
44928\end{array}$ & 69.8 & 9075 & 354 & 178 & 241 & 83 & 162 & 9 & 56 & 40 & 275 & 100 & 117 & 144 & 6.85 & 1232 & $12 / 17 / 08$ \\
\hline $\begin{array}{l}\text { Halomicrobium mukohataei } \\
\text { DSM } 12286 \text {, Contig } 62\end{array}$ & 65.6 & 3205 & 85 & 33 & 76 & 43 & 55 & 2 & 6 & 8 & 79 & 41 & 21 & 46 & 6.75 & 322 & $12 / 18 / 08$ \\
\hline $\begin{array}{l}\text { Halomicrobium mukohataei } \\
\text { DSM 12286, Contig } 61\end{array}$ & 65.6 & 190 & 9 & 7 & 8 & 2 & 8 & 2 & 2 & 0 & 12 & 12 & 6 & 18 & 6.75 & 42 & $12 / 18 / 08$ \\
\hline $\begin{array}{l}\text { Dyadobacter fermentans DSM } \\
18053\end{array}$ & 51.5 & 5851 & 230 & 112 & 142 & 80 & 144 & 3 & 71 & 51 & 161 & 53 & 100 & 88 & 7.4 & 827 & $12 / 18 / 08$ \\
\hline $\begin{array}{l}\text { Halorhabdus utahensis DSM } \\
12940\end{array}$ & 62.9 & 3047 & 90 & 24 & 88 & 62 & 70 & 2 & 15 & 15 & 72 & 19 & 39 & 29 & 5.68 & 364 & $12 / 19 / 08$ \\
\hline Meiothermus ruber DSM 1279 & 63.4 & 3083 & 114 & 52 & 40 & 27 & 55 & 0 & 22 & 23 & 58 & 22 & 51 & 40 & 6.23 & 353 & $12 / 19 / 08$ \\
\hline $\begin{array}{l}\text { Pedobacter heparinus DSM } \\
2366\end{array}$ & 42 & 4314 & 122 & 73 & 72 & 49 & 74 & 3 & 34 & 43 & 79 & 30 & 59 & 41 & 5.84 & 456 & $12 / 19 / 08$ \\
\hline $\begin{array}{l}\text { Anaerococcus prevotii DSM } \\
20548 \text {, Contig } 723\end{array}$ & 36.1 & 1735 & 60 & 29 & 16 & 8 & 18 & 0 & 19 & 12 & 47 & 20 & 20 & 38 & 7.66 & 177 & $12 / 19 / 08$ \\
\hline $\begin{array}{l}\text { Anaerococcus prevotii DSM } \\
20548 \text {, Contig } 698\end{array}$ & 36.1 & 106 & 5 & 5 & 0 & 1 & 5 & 0 & 2 & 0 & 15 & 9 & 2 & 9 & 7.66 & 30 & $12 / 19 / 08$ \\
\hline $\begin{array}{l}\text { Sphaerobacter thermophilus } \\
\text { DSM } 20745\end{array}$ & 68.1 & 2466 & 91 & 30 & 48 & 26 & 42 & 2 & 6 & 8 & 36 & 10 & 15 & 24 & 4.26 & 266 & $12 / 22 / 08$ \\
\hline $\begin{array}{l}\text { Thermobispora bispora DSM } \\
43833\end{array}$ & 72.4 & 3604 & 169 & 96 & 55 & 38 & 55 & 2 & 28 & 26 & 107 & 42 & 47 & 48 & 7.52 & 477 & $12 / 22 / 08$ \\
\hline Pirellula staleyi DSM 6068 & 57.5 & 4819 & 106 & 38 & 163 & 102 & 172 & 5 & 38 & 12 & 65 & 27 & 71 & 54 & 6.06 & 642 & $12 / 22 / 08$ \\
\hline Eggerthella lenta DSM 02243 & 64.2 & 3113 & 86 & 40 & 100 & 60 & 54 & 3 & 21 & 18 & 61 & 32 & 22 & 52 & 6.62 & 357 & $12 / 22 / 08$ \\
\hline $\begin{array}{l}\text { Planctomyces limnophilus DSM } \\
3776 \text {, Contig } 476\end{array}$ & 54 & 4292 & 87 & 27 & 149 & 116 & 235 & 4 & 15 & 8 & 51 & 21 & 68 & 47 & 6.5 & 659 & $12 / 22 / 08$ \\
\hline $\begin{array}{l}\text { Planctomyces limnophilus DSM } \\
3776 \text {, Contig } 422\end{array}$ & 54 & 61 & 4 & 1 & 0 & 0 & 9 & 0 & 0 & 0 & 1 & 1 & 2 & 0 & 6.5 & 16 & $12 / 22 / 08$ \\
\hline $\begin{array}{l}\text { Streptosporangium roseum } \\
\text { DSM 43021, Contig } 236\end{array}$ & 70.87 & 9281 & 448 & 402 & 191 & 139 & 205 & 5 & 59 & 85 & 431 & 211 & 101 & 435 & 13.91 & 1541 & $12 / 22 / 08$ \\
\hline $\begin{array}{l}\text { Streptosporangium roseum } \\
\text { DSM 43021, Contig } 206\end{array}$ & 70.87 & 33 & 5 & 1 & 0 & 0 & 1 & 0 & 3 & 2 & 2 & 2 & 3 & 2 & 13.91 & 11 & $12 / 22 / 08$ \\
\hline
\end{tabular}




\begin{tabular}{|c|c|c|c|c|c|c|c|c|c|c|c|c|c|c|c|c|c|}
\hline $\begin{array}{l}\text { Atopobium parvulum DSM } \\
20469 \text {, Contig } 22\end{array}$ & 45.69 & 1367 & 26 & 13 & 65 & 20 & 21 & 0 & 1 & 2 & 26 & 9 & 7 & 16 & 4.75 & 154 & $1 / 13 / 09$ \\
\hline $\begin{array}{l}\text { Jonesia denitrificans DSM } \\
\text { 20603, Contig } 118\end{array}$ & 58.42 & 2596 & 90 & 48 & 68 & 72 & 86 & 1 & 16 & 10 & 44 & 19 & 59 & 47 & 9.44 & 403 & $1 / 13 / 09$ \\
\hline $\begin{array}{l}\text { Rhodothermus marinus DSM } \\
4252 \text {, Contig } 87\end{array}$ & 64.54 & 112 & 12 & 8 & 4 & 4 & 6 & 1 & 3 & 0 & 11 & 13 & 10 & 10 & 7.01 & 45 & $1 / 14 / 09$ \\
\hline $\begin{array}{l}\text { Kangiella koreensis DSM } \\
16069 \text {, Contig } 47\end{array}$ & 43.69 & 2655 & 64 & 37 & 49 & 36 & 35 & 1 & 2 & 4 & 35 & 13 & 23 & 16 & 4.71 & 225 & $1 / 14 / 09$ \\
\hline $\begin{array}{l}\text { Veillonella parvula DSM } 2008, \\
\text { Contig } 46\end{array}$ & 38.63 & 1865 & 38 & 20 & 25 & 15 & 21 & 2 & 18 & 16 & 17 & 17 & 15 & 16 & 4.45 & 154 & $1 / 14 / 09$ \\
\hline $\begin{array}{l}\text { Rhodothermus marinus DSM } \\
4252 \text {, Contig } 88\end{array}$ & 64.54 & 2811 & 74 & 34 & 52 & 31 & 25 & 0 & 26 & 22 & 43 & 25 & 27 & 43 & 7.01 & 302 & $1 / 14 / 09$ \\
\hline $\begin{array}{l}\text { Xylanimonas cellulosilytica } \\
\text { DSM 15894, Contig } 38 \\
\end{array}$ & 72.5 & 104 & 6 & 1 & 1 & 0 & 2 & 0 & 0 & 0 & 4 & 2 & 0 & 0 & 5.66 & 13 & $1 / 14 / 09$ \\
\hline $\begin{array}{l}\text { Streptobacillus moniliformis } \\
\text { DSM 12112, Contig } 187\end{array}$ & 26.31 & 8 & 0 & 0 & 0 & 0 & 0 & 0 & 0 & 0 & 0 & 0 & 0 & 0 & 14.62 & 0 & $1 / 14 / 09$ \\
\hline $\begin{array}{l}\text { Thermobaculum terrenum } \\
\text { ATCC BAA-798, Contig } 144\end{array}$ & 63.76 & 1004 & 50 & 17 & 17 & 16 & 27 & 2 & 12 & 14 & 20 & 14 & 19 & 22 & 6.65 & 149 & $1 / 14 / 09$ \\
\hline $\begin{array}{l}\text { Streptobacillus moniliformis } \\
\text { DSM } 12112 \text {, Contig } 186\end{array}$ & 26.31 & 1538 & 73 & 45 & 19 & 12 & 26 & 0 & 47 & 23 & 58 & 35 & 65 & 69 & 14.62 & 265 & $1 / 14 / 09$ \\
\hline $\begin{array}{l}\text { Thermobaculum terrenum } \\
\text { ATCC BAA-798, Contig } 145\end{array}$ & 48.07 & 1895 & 53 & 32 & 39 & 21 & 38 & 0 & 8 & 4 & 33 & 10 & 25 & 17 & 6.65 & 207 & $1 / 14 / 09$ \\
\hline $\begin{array}{l}\text { Xylanimonas cellulosilytica } \\
\text { DSM } 15894, \text { Contig } 570\end{array}$ & 72.5 & 3375 & 114 & 65 & 67 & 41 & 37 & 1 & 22 & 10 & 79 & 24 & 23 & 41 & 5.66 & 341 & $1 / 14 / 09$ \\
\hline $\begin{array}{l}\text { Chitinophaga pinensis DSM } \\
2588 \text {, Contig } 402\end{array}$ & 45.23 & 7332 & 219 & 110 & 147 & 96 & 223 & 5 & 75 & 37 & 141 & 82 & 114 & 110 & 6.98 & 939 & $1 / 27 / 09$ \\
\hline $\begin{array}{l}\text { Desulfotomaculum acetoxidans } \\
\text { DSM } 771 \text {, Contig } 96\end{array}$ & 41.55 & 4368 & 194 & 137 & 79 & 88 & 210 & 4 & 110 & 78 & 235 & 196 & 178 & 304 & 20.67 & 1002 & $1 / 28 / 09$ \\
\hline $\begin{array}{l}\text { Sulfurospirillum deleyianum } \\
\text { DSM 6946, Contig } 103\end{array}$ & 39 & 2294 & 49 & 27 & 13 & 14 & 21 & 0 & 6 & 8 & 26 & 14 & 16 & 27 & 4.27 & 170 & $8 / 17 / 09$ \\
\hline $\begin{array}{l}\text { Thermomonospora curvata } \\
\text { DSM 43183, Contig } 146\end{array}$ & 71.64 & 5009 & 211 & 107 & 74 & 60 & 100 & 4 & 60 & 39 & 131 & 58 & 68 & 99 & 7.83 & 678 & $2 / 3 / 09$ \\
\hline $\begin{array}{l}\text { Thermanaerovibrio } \\
\text { acidaminovorans DSM } 6589 \text {, } \\
\text { Contig } 128\end{array}$ & 63.79 & 1764 & 69 & 45 & 24 & 9 & 14 & 0 & 21 & 17 & 29 & 23 & 22 & 27 & 7.14 & 211 & $2 / 19 / 09$ \\
\hline $\begin{array}{l}\text { Stackebrandtia nassauensis } \\
\text { DSM 44728, Contig } 197\end{array}$ & 68.13 & 6456 & 260 & 121 & 108 & 94 & 95 & 2 & 21 & 13 & 154 & 75 & 51 & 108 & 6.95 & 809 & 2/20/09 \\
\hline
\end{tabular}




\begin{tabular}{|c|c|c|c|c|c|c|c|c|c|c|c|c|c|c|c|c|c|}
\hline $\begin{array}{l}\text { Haloterrigena turkmenica DSM } \\
5511 \text {, Contig } 83\end{array}$ & 65.8 & 195 & 18 & 14 & 4 & 6 & 17 & 1 & 3 & 0 & 46 & 38 & 15 & 43 & 10.7 & 92 & 7/9/09 \\
\hline $\begin{array}{l}\text { Haloterrigena turkmenica DSM } \\
5511 \text {, Contig } 81\end{array}$ & 65.8 & 159 & 5 & 1 & 7 & 0 & 2 & 0 & 0 & 2 & 2 & 1 & 0 & 0 & 10.7 & 19 & 7/9/09 \\
\hline $\begin{array}{l}\text { Haloterrigena turkmenica DSM } \\
5511 \text {, Contig } 82\end{array}$ & 65.8 & 96 & 6 & 2 & 0 & 0 & 8 & 0 & 0 & 0 & 4 & 2 & 0 & 1 & 10.7 & 18 & 7/9/09 \\
\hline $\begin{array}{l}\text { Haloterrigena turkmenica DSM } \\
5511 \text {, Contig } 80\end{array}$ & 65.8 & 21 & 0 & 0 & 0 & 0 & 1 & 0 & 0 & 0 & 1 & 1 & 0 & 1 & 10.7 & 2 & 7/9/09 \\
\hline $\begin{array}{l}\text { Methanohalophilus mahii DSM } \\
\text { 5219, Contig } 30\end{array}$ & 42.62 & 2035 & 64 & 31 & 35 & 32 & 34 & 1 & 48 & 22 & 72 & 30 & 29 & 45 & 8.21 & 291 & $3 / 11 / 09$ \\
\hline $\begin{array}{l}\text { Nakamurella multipartita DSM } \\
44233 \text {, Contig } 351\end{array}$ & 70.92 & 5486 & 277 & 157 & 177 & 134 & 57 & 3 & 117 & 136 & 207 & 84 & 141 & 174 & 12.58 & 996 & $3 / 11 / 09$ \\
\hline $\begin{array}{l}\text { Archaeoglobus profundus DSM } \\
5631 \text {, Contig } 188\end{array}$ & 39.84 & 4 & 0 & 0 & 0 & 0 & 0 & 0 & 0 & 0 & 0 & 0 & 0 & 0 & 6.93 & 0 & $3 / 17 / 09$ \\
\hline $\begin{array}{l}\text { Spirosoma linguale DSM } 74, \\
\text { Contig } 241\end{array}$ & 50.19 & 41 & 3 & 2 & 1 & 1 & 4 & 0 & 0 & 2 & 2 & 0 & 0 & 1 & 8.47 & 14 & $3 / 17 / 09$ \\
\hline $\begin{array}{l}\text { Spirosoma linguale DSM 74, } \\
\text { Contig } 233\end{array}$ & 50.19 & 10 & 0 & 0 & 0 & 0 & 1 & 0 & 0 & 0 & 0 & 0 & 0 & 0 & 8.47 & 1 & $3 / 17 / 09$ \\
\hline $\begin{array}{l}\text { Spirosoma linguale DSM 74, } \\
\text { Contig } 224\end{array}$ & 50.19 & 9 & 2 & 0 & 0 & 0 & 1 & 0 & 0 & 0 & 0 & 0 & 1 & 0 & 8.47 & 3 & $3 / 17 / 09$ \\
\hline $\begin{array}{l}\text { Spirosoma linguale DSM 74, } \\
\text { Contig } 225\end{array}$ & 50.19 & 11 & 0 & 0 & 0 & 0 & 0 & 0 & 0 & 0 & 0 & 0 & 0 & 0 & 8.47 & 0 & $3 / 17 / 09$ \\
\hline $\begin{array}{l}\text { Spirosoma linguale DSM 74, } \\
\text { Contig } 226\end{array}$ & 50.19 & 14 & 0 & 0 & 0 & 1 & 0 & 0 & 0 & 0 & 0 & 0 & 0 & 0 & 8.47 & 2 & $3 / 17 / 09$ \\
\hline $\begin{array}{l}\text { Spirosoma linguale DSM 74, } \\
\text { Contig } 227\end{array}$ & 50.19 & 11 & 2 & 1 & 0 & 0 & 1 & 0 & 0 & 0 & 1 & 1 & 0 & 0 & 8.47 & 4 & $3 / 17 / 09$ \\
\hline $\begin{array}{l}\text { Sebaldella termitidis ATCC } \\
33386 \text {, Contig } 68\end{array}$ & 33.45 & 16 & 0 & 0 & 0 & 0 & 0 & 0 & 0 & 0 & 0 & 0 & 0 & 0 & 4.59 & 0 & $3 / 17 / 09$ \\
\hline $\begin{array}{l}\text { Spirosoma linguale DSM 74, } \\
\text { Contig } 247\end{array}$ & 50.19 & 185 & 8 & 4 & 5 & 4 & 10 & 1 & 4 & 2 & 9 & 8 & 8 & 8 & 8.47 & 39 & $3 / 17 / 09$ \\
\hline $\begin{array}{l}\text { Sebaldella termitidis ATCC } \\
33386 \text {, Contig } 69\end{array}$ & 33.45 & 53 & 4 & 1 & 1 & 1 & 1 & 0 & 0 & 0 & 3 & 3 & 1 & 4 & 4.59 & 12 & $3 / 17 / 09$ \\
\hline $\begin{array}{l}\text { Spirosoma linguale DSM 74, } \\
\text { Contig } 234\end{array}$ & 50.19 & 152 & 3 & 3 & 2 & 3 & 5 & 0 & 6 & 4 & 5 & 2 & 7 & 5 & 8.47 & 27 & $3 / 17 / 09$ \\
\hline $\begin{array}{l}\text { Archaeoglobus profundus DSM } \\
5631 \text {, Contig } 189\end{array}$ & 39.84 & 1872 & 77 & 29 & 24 & 26 & 46 & 1 & 23 & 20 & 28 & 11 & 29 & 35 & 6.93 & 300 & $3 / 17 / 09$ \\
\hline
\end{tabular}


Sebaldella termitidis ATCC

33386, Contig 70

Spirosoma linguale DSM 74,

Contig 279

Conexibacter woesei DSM

14684, Contig 121

Denitrovibrio acetiphilus DSM

12809, Contig 92

Haloterrigena turkmenica DSM

5511, Contig 84

Haliangium ochraceum DSM

14365, Contig 199

Desulfohalobium retbaense

DSM 5692, Contig 73

Gordonia bronchialis DSM

43247, Contig 180

Desulfohalobium retbaense

DSM 5692, Contig 76

Gordonia bronchialis DSM

43247, Contig 194

Alicyclobacillus acidocaldarius

DSM 446, Contig 108

Alicyclobacillus acidocaldarius

DSM 446, Contig 109

Alicyclobacillus acidocaldarius

DSM 446, Contig 110

Alicyclobacillus acidocaldarius

DSM 446, Contig 111

Kribbella flavida DSM 17836

Haloterrigena turkmenica DSM

5511, Contig 85

Haloterrigena turkmenica DSM

5511, Contig 86

Tsukamurella paurometabola

DSM 20162, Contig 105

Thermosphaera aggregans DSM

11486, Contig 48

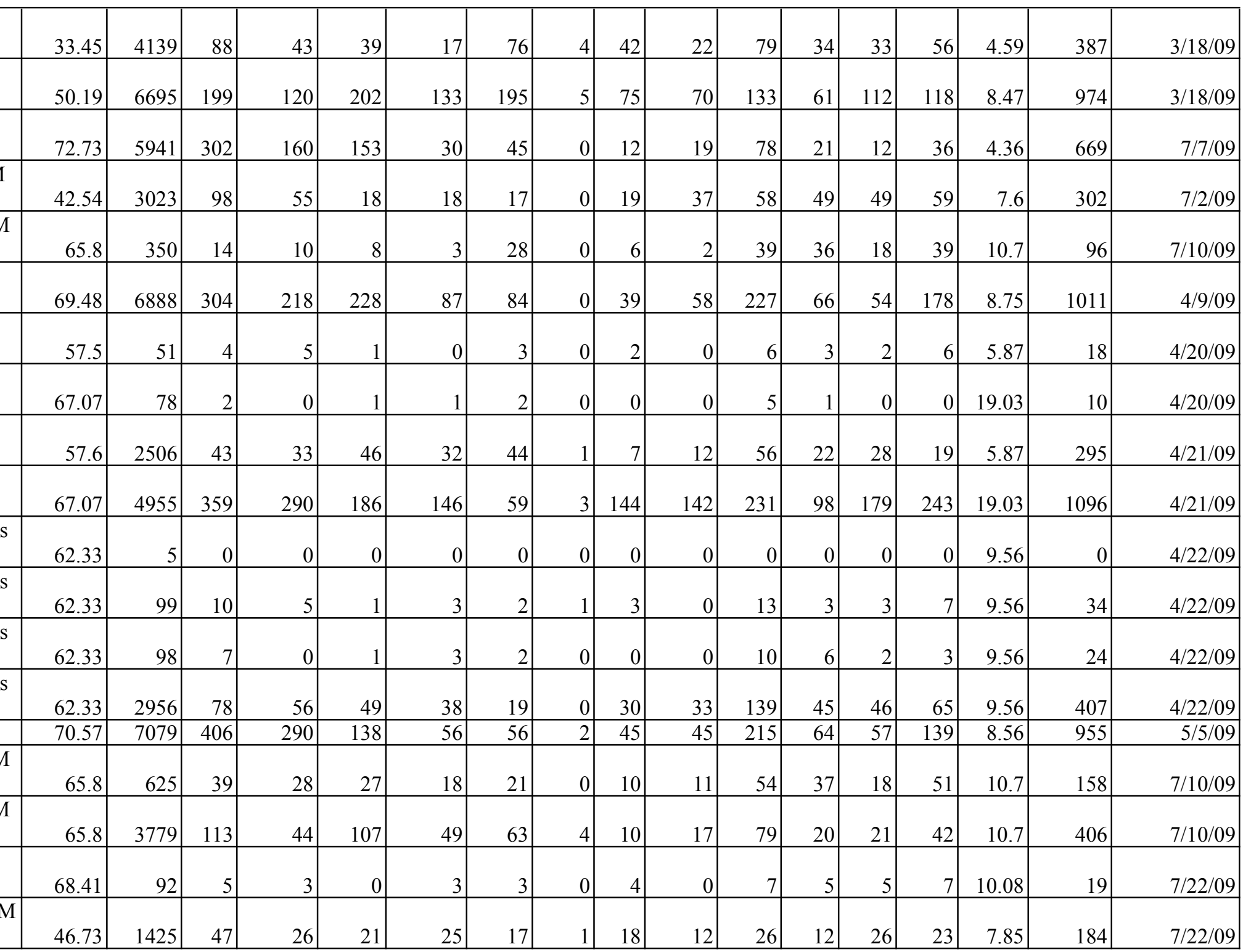




\begin{tabular}{|c|c|c|c|c|c|c|c|c|c|c|c|c|c|c|c|c|c|}
\hline $\begin{array}{l}\text { Tsukamurella paurometabola } \\
\text { DSM 20162, Contig } 106\end{array}$ & 68.41 & 4254 & 223 & 164 & 100 & 62 & 39 & 4 & 32 & 50 & 122 & 46 & 57 & 86 & 10.08 & 595 & 7/22/09 \\
\hline $\begin{array}{l}\text { Aminobacterium colombiense } \\
\text { DSM 12261, Contig } 324\end{array}$ & 45.31 & 1921 & 54 & 31 & 34 & 28 & 45 & 0 & 12 & 14 & 39 & 25 & 31 & 38 & 7.96 & 252 & $7 / 23 / 09$ \\
\hline \begin{tabular}{|l|} 
Ignisphaera aggregans DSM \\
17230
\end{tabular} & 35.69 & 2029 & 69 & 54 & 45 & 33 & 87 & 2 & 22 & 16 & 41 & 31 & 59 & 62 & 11.78 & 344 & $7 / 28 / 09$ \\
\hline $\begin{array}{l}\text { Sphaerobacter thermophilus } \\
\text { DSM 20745, Contig } 4369\end{array}$ & 68.12 & 1069 & 33 & 26 & 28 & 8 & 10 & 0 & 10 & 10 & 33 & 9 & 14 & 16 & 6.83 & 133 & 7/31/09 \\
\hline $\begin{array}{l}\text { Ferrimonas balearica DSM } \\
9799 \text {, Contig } 117\end{array}$ & 60.22 & 3799 & 100 & 76 & 38 & 37 & 30 & 5 & 6 & 10 & 71 & 15 & 10 & 21 & 4.19 & 300 & 7/31/09 \\
\hline $\begin{array}{l}\text { Geodermatophilus obscurus } \\
\text { DSM } 43160\end{array}$ & 73.98 & 5116 & 346 & 198 & 179 & 101 & 78 & 1 & 80 & 33 & 286 & 98 & 299 & 247 & 14.89 & 1065 & $8 / 5 / 09$ \\
\hline $\begin{array}{l}\text { Thermocrinis albus DSM } \\
14484 \text {, Contig } 4 \\
\end{array}$ & 46.93 & 1632 & 45 & 26 & 5 & 6 & 34 & 2 & 5 & 8 & 29 & 12 & 37 & 10 & 5.58 & 246 & $8 / 22 / 09$ \\
\hline $\begin{array}{l}\text { Spirochaeta smaragdinae DSM } \\
11293\end{array}$ & 0 & 4415 & 130 & 0 & 81 & 0 & 83 & 1 & 152 & 26 & 108 & 0 & 0 & 0 & 0 & 689 & $9 / 14 / 09$ \\
\hline $\begin{array}{l}\text { Methanothermus fervidus DSM } \\
2088 \text {, Contig } 16\end{array}$ & 31.64 & 1318 & 27 & 30 & 15 & 6 & 9 & 0 & 22 & 16 & 16 & 8 & 23 & 18 & 6.45 & 135 & $11 / 10 / 09$ \\
\hline $\begin{array}{l}\text { Ilyobacter polytropus DSM } \\
2926 \text {, Contig } 58\end{array}$ & 34.53 & 125 & 9 & 4 & 1 & 4 & 1 & 0 & 4 & 0 & 13 & 12 & 10 & 19 & 8.66 & 29 & $10 / 9 / 09$ \\
\hline $\begin{array}{l}\text { Ilyobacter polytropus DSM } \\
2926 \text {, Contig } 59\end{array}$ & 34.53 & 912 & 26 & 18 & 13 & 4 & 30 & 0 & 14 & 16 & 26 & 15 & 27 & 23 & 8.66 & 118 & $10 / 10 / 09$ \\
\hline $\begin{array}{l}\text { Ilyobacter polytropus DSM } \\
2926 \text {, Contig } 60\end{array}$ & 34.53 & 1929 & 49 & 35 & 30 & 9 & 48 & 2 & 28 & 33 & 29 & 14 & 34 & 29 & 8.66 & 216 & $10 / 10 / 09$ \\
\hline $\begin{array}{l}\text { Acetohalobium arabaticum } \\
\text { DSM 5501, Contig } 136 \\
\end{array}$ & 36.63 & 2353 & 66 & 57 & 28 & 28 & 41 & 3 & 36 & 36 & 81 & 39 & 36 & 71 & 9.82 & 300 & $10 / 10 / 09$ \\
\hline $\begin{array}{l}\text { Acidaminococcus fermentans } \\
\text { DSM 20731, Contig } 169\end{array}$ & 55.84 & 2054 & 55 & 46 & 15 & 12 & 24 & 1 & 19 & 5 & 78 & 61 & 20 & 66 & 9.98 & 232 & $10 / 12 / 09$ \\
\hline Olsenella uli DSM 7084 & 64.7 & 1773 & 32 & 33 & 74 & 23 & 1 & 0 & 5 & 2 & 76 & 30 & 16 & 47 & 8.4 & 213 & $11 / 20 / 09$ \\
\hline $\begin{array}{l}\text { Segniliparus rotundus DSM } \\
44985 \text {, Contig } 67\end{array}$ & 66.79 & 3071 & 102 & 93 & 60 & 30 & 119 & 0 & 26 & 4 & 138 & 38 & 35 & 68 & 8.6 & 522 & $11 / 9 / 09$ \\
\hline $\begin{array}{l}\text { Bacillus tusciae DSM 2912, } \\
\text { Contig } 79\end{array}$ & 59.11 & 3320 & 126 & 99 & 69 & 83 & 102 & 2 & 40 & 20 & 230 & 92 & 85 & 173 & 16.02 & 745 & $10 / 27 / 09$ \\
\hline \begin{tabular}{|l|} 
Brachyspira murdochii DSM \\
12563 , Contig 316
\end{tabular} & 27.75 & 2867 & 43 & 25 & 23 & 10 & 96 & 0 & 42 & 4 & 92 & 19 & 32 & 45 & 4.57 & 328 & $10 / 28 / 09$ \\
\hline $\begin{array}{l}\text { Cellulomonas flavigena DSM } \\
20109 \text {, Contig } 371\end{array}$ & 74.29 & 3721 & 84 & 56 & 84 & 48 & 78 & 0 & 18 & 0 & 256 & 17 & 8 & 52 & 4.86 & 561 & $10 / 28 / 09$ \\
\hline
\end{tabular}




\begin{tabular}{|c|c|c|c|c|c|c|c|c|c|c|c|c|c|c|c|c|c|}
\hline $\begin{array}{l}\text { Arcobacter nitrofigilis DSM } \\
7299 \text {, Contig } 168\end{array}$ & 28.36 & 3144 & 42 & 36 & 26 & 14 & 4 & 0 & 14 & 10 & 37 & 17 & 11 & 24 & 3.24 & 157 & $11 / 24 / 09$ \\
\hline $\begin{array}{l}\text { Spirochaeta smaragdinae DSM } \\
11293 \text {, Contig } 531\end{array}$ & 0 & 4331 & 103 & 0 & 77 & 0 & 0 & 0 & 60 & 52 & 99 & 0 & 0 & 0 & 0 & 440 & $11 / 29 / 09$ \\
\hline $\begin{array}{l}\text { Coraliomargarita akajimensis } \\
\text { DSM } 45221\end{array}$ & 53.6 & 3145 & 62 & 51 & 97 & 57 & 101 & 0 & 2 & 11 & 63 & 9 & 13 & 16 & 4.64 & 389 & $12 / 17 / 09$ \\
\hline $\begin{array}{l}\text { Nocardiopsis dassonvillei DSM } \\
43111 \text {, Contig } 412\end{array}$ & 0 & 703 & 14 & 0 & 16 & 0 & 21 & 0 & 0 & 0 & 72 & 0 & 0 & 0 & 0 & 128 & $12 / 22 / 09$ \\
\hline $\begin{array}{l}\text { Nocardiopsis dassonvillei DSM } \\
43111 \text {, Contig } 768\end{array}$ & 0 & 4859 & 129 & 0 & 113 & 0 & 121 & 0 & 20 & 10 & 589 & 0 & 0 & 0 & 0 & 1024 & $12 / 22 / 09$ \\
\hline $\begin{array}{l}\text { Meiothermus silvanus DSM } \\
9946, \text { Contig } 2050\end{array}$ & 0 & 341 & 20 & 0 & 5 & 0 & 15 & 0 & 8 & 2 & 28 & 0 & 0 & 0 & 0 & 92 & $1 / 21 / 10$ \\
\hline $\begin{array}{l}\text { Meiothermus silvanus DSM } \\
\text { 9946, Contig } 1115\end{array}$ & 0 & 139 & 7 & 0 & 1 & 0 & 17 & 0 & 0 & 0 & 4 & 0 & 0 & 0 & 0 & 34 & $1 / 21 / 10$ \\
\hline $\begin{array}{l}\text { Meiothermus silvanus DSM } \\
\text { 9946, Contig } 2054\end{array}$ & 0 & 3229 & 95 & 0 & 53 & 0 & 80 & 0 & 39 & 35 & 125 & 0 & 0 & 0 & 0 & 476 & $1 / 22 / 10$ \\
\hline $\begin{array}{l}\text { Ktedonobacter racemifer DSM } \\
44963\end{array}$ & 0 & 13083 & 551 & 0 & 418 & 0 & 1275 & 0 & 468 & 396 & 851 & 0 & 0 & 0 & 0 & 4339 & $2 / 1 / 10$ \\
\hline $\begin{array}{l}\text { Aminomonas paucivorans DSM } \\
12260 \text {, Contig } 78\end{array}$ & 0 & 2429 & 61 & 0 & 32 & 0 & 34 & 0 & 7 & 11 & 93 & 0 & 0 & 0 & 0 & 273 & $2 / 4 / 10$ \\
\hline Contigs from GBP & $\begin{array}{l}\text { Genome } \\
\text { GC\% }\end{array}$ & CDSs & \begin{tabular}{|l|} 
Shor \\
t \\
gene \\
s
\end{tabular} & \begin{tabular}{|l|} 
Extend \\
ed \\
short \\
genes
\end{tabular} & $\begin{array}{l}\text { Long } \\
\text { genes }\end{array}$ & $\begin{array}{l}\text { Trimme } \\
\text { d long } \\
\text { genes }\end{array}$ & \begin{tabular}{|l|} 
Uniqu \\
e \\
genes
\end{tabular} & \begin{tabular}{|l|} 
Dubi \\
ous \\
genes
\end{tabular} & \begin{tabular}{|l|} 
Bro \\
ken \\
gene \\
s
\end{tabular} & \begin{tabular}{|l|} 
Interu \\
pted \\
genes
\end{tabular} & \begin{tabular}{|l|} 
Misse \\
d \\
genes
\end{tabular} & \begin{tabular}{|l|} 
Adde \\
d \\
genes
\end{tabular} & $\begin{array}{l}\text { Delet } \\
\text { ed } \\
\text { genes }\end{array}$ & \begin{tabular}{|l|} 
Pseud \\
o \\
genes
\end{tabular} & $\begin{array}{l}\text { \% } \\
\text { correc } \\
\text { tions }\end{array}$ & \begin{tabular}{|l|} 
Total \\
number \\
of \\
anomali \\
es \\
\end{tabular} & Date \\
\hline $\begin{array}{l}\text { Mycobacterium sp. Spyr1, } \\
\text { Chromosome (GeneMark) }\end{array}$ & 0 & 5321 & 506 & 0 & 73 & 0 & 45 & 11 & 20 & 52 & 558 & 0 & 0 & 0 & 0 & 1326 & $10 / 28 / 08$ \\
\hline $\begin{array}{l}\text { Mycobacterium sp. Spyr1, } \\
\text { Chromosome (Prodigal) }\end{array}$ & 67.9 & 5302 & 311 & 308 & 67 & 76 & 23 & 2 & 20 & 55 & 416 & 89 & 98 & 153 & 15.4 & 943 & $10 / 29 / 08$ \\
\hline $\begin{array}{l}\text { Mycobacterium sp. Spyr1, } \\
\text { Plasmid } 1\end{array}$ & 67.9 & 234 & 20 & 17 & 6 & 8 & 10 & UNAY & 0 & 0 & 37 & 17 & 28 & 26 & 15.4 & 81 & $11 / 11 / 08$ \\
\hline $\begin{array}{l}\text { Mycobacterium sp. Spyr1, } \\
\text { Plasmid } 2\end{array}$ & 67.9 & 48 & 3 & 6 & 2 & 5 & 19 & UNAY & 0 & 0 & 7 & 2 & 24 & 3 & 15.4 & 32 & $11 / 11 / 08$ \\
\hline $\begin{array}{l}\text { Pichia stipitis CBS 6054, } \\
\text { chromosome } 1\end{array}$ & UNAVAI & 1276 & 64 & UNAVA & 16 & UNAVA & 38 & UNAY & 5 & 2 & 164 & UNAY & UNAI & UNAY & UNAVA & 289 & $1 / 12 / 09$ \\
\hline
\end{tabular}




\begin{tabular}{|c|c|c|c|c|c|c|c|c|c|c|c|c|c|c|c|c|c|}
\hline $\begin{array}{l}\text { Pichia stipitis CBS } 6054, \\
\text { chromosome } 2\end{array}$ & UNAVAI & 1046 & 69 & UNAVA & 15 & UNAVA & 19 & UNAY & 0 & 0 & 117 & UNAY & UNAY & UNAY & UNAVA & 220 & $1 / 12 / 09$ \\
\hline $\begin{array}{l}\text { Pichia stipitis CBS 6054, } \\
\text { chromosome } 3\end{array}$ & UNAVAI & 690 & 40 & UNAVA & 11 & UNAVA & 13 & UNAY & 0 & 2 & 97 & UNAY & UNAY & UNAY & UNAVA & 163 & $1 / 12 / 09$ \\
\hline $\begin{array}{l}\text { Pichia stipitis CBS } 6054, \\
\text { chromosome } 4\end{array}$ & UNAVAI & 693 & 43 & UNAVA & 5 & UNAVA & 16 & UNAY & 2 & 4 & 93 & UNAY & UNAY & UNAY & UNAVA & 163 & $1 / 12 / 09$ \\
\hline $\begin{array}{l}\text { Pichia stipitis CBS } 6054, \\
\text { chromosome } 5\end{array}$ & UNAVAI & 679 & 44 & UNAVA & 10 & UNAVA & 21 & UNAY & 2 & 6 & 84 & UNAV & UNAY & UNAY & UNAVA & 164 & $1 / 12 / 09$ \\
\hline $\begin{array}{l}\text { Pichia stipitis CBS 6054, } \\
\text { chromosome } 6\end{array}$ & UNAVAI & 685 & 41 & UNAVA & 4 & UNAVA & 16 & UNAY & 0 & 2 & 83 & UNAY & UNAY & UNAY & UNAVA & 146 & $1 / 12 / 09$ \\
\hline $\begin{array}{l}\text { Pichia stipitis CBS 6054, } \\
\text { chromosome } 7\end{array}$ & UNAVAI & 383 & 19 & UNAVA & 3 & UNAVA & 8 & UNAY & 0 & 0 & 6 & UNAV & UNAY & UNAY & UNAVA & 36 & $1 / 12 / 09$ \\
\hline $\begin{array}{l}\text { Pichia stipitis CBS 6054, } \\
\text { chromosome } 8\end{array}$ & UNAVAI & 364 & 30 & UNAVA & 2 & UNAVA & 9 & UNAY & 0 & 0 & 53 & UNAY & UNAY & UNAY & UNAVA & 94 & $1 / 12 / 09$ \\
\hline $\begin{array}{l}\text { Methanosphaerula palustris E1- } \\
9 \mathrm{c}\end{array}$ & UNAVAI & 3177 & 115 & UNAVA & 294 & UNAVA & 277 & UNAY & 71 & 60 & 106 & UNAY & UNAY & UNAY & UNAVA & 1340 & $1 / 30 / 09$ \\
\hline Mycobacterium sp. Spyr1 & UNAVAI & 4888 & 79 & UNAVA & 992 & UNAVA & 99 & UNAY & 34 & 53 & 658 & UNAY & UNAY & UNAY & UNAVA & 2705 & $1 / 30 / 09$ \\
\hline $\begin{array}{l}\text { Aspergillus fumigatus Af293, } \\
\text { chromosome } 1\end{array}$ & UNAVAI & 1612 & 76 & UNAVA & 54 & UNAVA & 195 & UNAY & 44 & 4 & 518 & UNAY & UNAY & UNAY & UNAVA & 885 & $2 / 18 / 09$ \\
\hline $\begin{array}{l}\text { Zymomonas mobilis, draft } \\
\text { genome, NCBI ID } 11163\end{array}$ & UNAVAI & 1348 & 52 & UNAVA & 38 & UNAVA & 35 & UNAY & 34 & 8 & 59 & UNAY & UNAY & UNAY & UNAVA & 265 & $3 / 23 / 09$ \\
\hline $\begin{array}{l}\text { Porphyromonas gingivalis } \\
\text { ATCC } 33277\end{array}$ & UNAVAI & 2094 & 68 & UNAVA & 46 & UNAVA & 93 & UNAY & 0 & 23 & 908 & UNAV & UNAY & UNAY & UNAVA & 1552 & $7 / 29 / 09$ \\
\hline
\end{tabular}


Supplementary Data 2: Gene models in Meth before manual curation

ftp://ftp.jgi-

psf.org/pub/JGI data/apati/GenePRIMP Supplementary_Data/meth before manual_cur ation.art

Supplementary Data 3: Gene models in Meth after manual curation

ftp://ftp.jgi-

psf.org/pub/JGI_data/apati/GenePRIMP_Supplementary_Data/meth_after_manual_curati on.art

Supplementary Data 4: Gene models in Myco before manual curation

ftp://ftp.jgi-

psf.org/pub/JGI data/apati/GenePRIMP Supplementary_Data/myco before manual_cur ation.gb

Supplementary Data 5: Gene models in Myco after manual curation

ftp://ftp.jgi-

psf.org/pub/JGI_data/apati/GenePRIMP_Supplementary_Data/myco_after_manual_curat ion.gb 